EGG-EEL-10752

\title{
SITING STUDY \\ FOR \\ TEST AREA NORTH POTABLE WATER \\ DEEP WELL PROJECT \\ FY-94 LL GPP
}

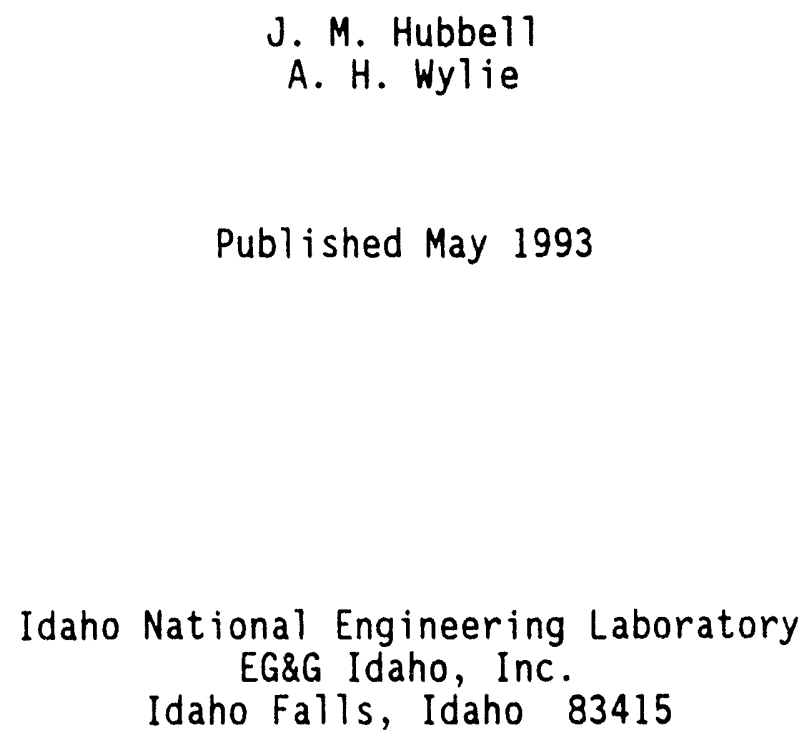

J. M. Hubbe 11

A. H. Wylie

Published May 1993

Idaho National Engineering Laboratory

EG\&G Idaho, Inc.

Idaho Falls, Idaho 83415

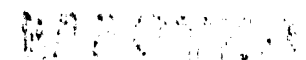

is 30,4004 
EGG-EEL-10752

\author{
SITING STUDY \\ FOR \\ TEST AREA NORTH POTABLE WATER \\ DEEP WELL PROJECT \\ FY-94 LL GPP
}

Reviewed by:
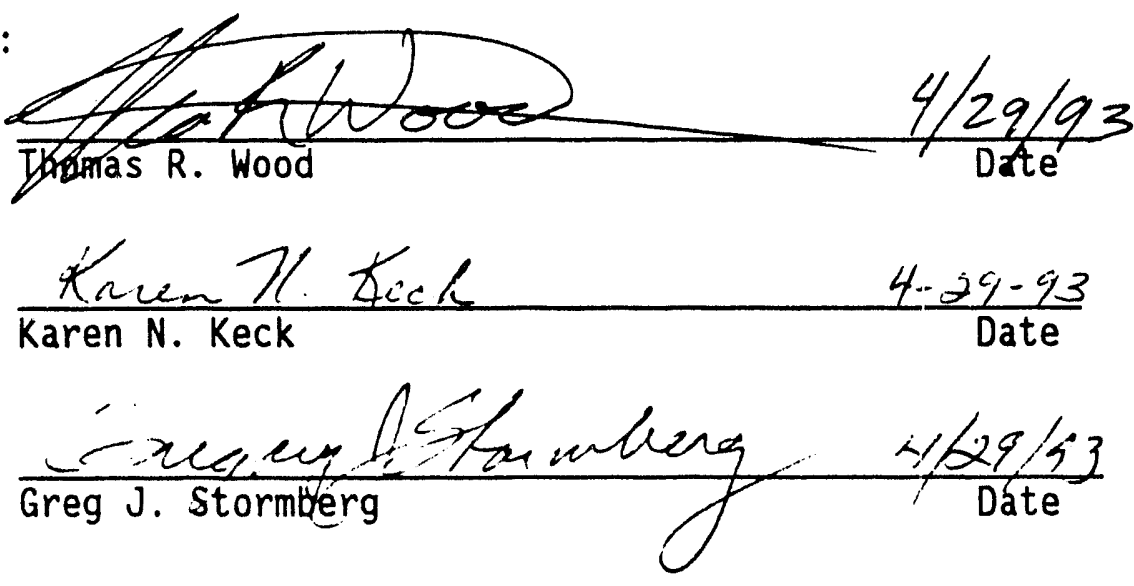

Approved by :

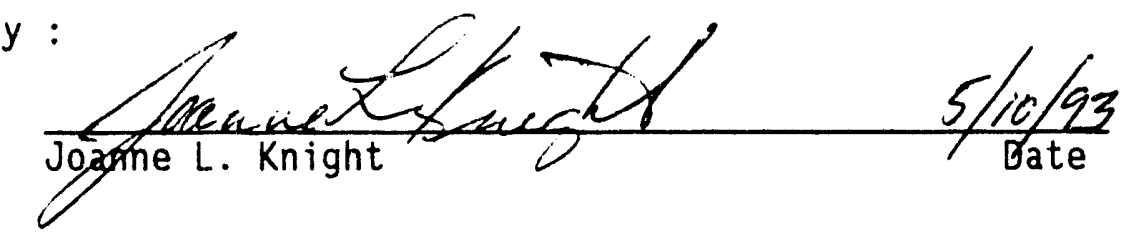




\section{ABSTRACT}

This study was conducted to evaluate the suitability of various locations for a new potabie ground water well at Test Area North (TAN). The new well is proposed to repiace two existing wells located within a trichloroethylene (TCE) plume. Several locations were evaluated using computer simulations based on the hydrogeology of the site. The modeling effort involved: 1) producing a water table map, 2) superimposing the effects of pumping the proposed new production well on the water table map using the model CAPZONE, and 3) calculating the capture zone for these wells using the GWPATH model. A three dimensional contaminant transport model was used to evaluate siting a well in a deeper horizon of the aquifer. The following scenarios were investigated: (1) placing a new well $500 \mathrm{ft}$ north of the existing wells; (2) locating a well $3000 \mathrm{ft}$ northwest of the existing wells; (3) deepening one of the existing welis 100 to $150 \mathrm{ft}$ to produce water from beneath an interbed that acts as a hydraulic barrier; and (4) drilling a new well about $500 \mathrm{ft}$ northwest of the existing wells to produce water from beneath the interbed. The recommended new well site (fourth scenario) is northwest of the existing wells, with the well completed from 500 to $600 \mathrm{ft}$ below land surface to produce water from beneath the $Q-R$ interbed. Locating the well northwest of the existing wells places the new well out of the TCE plume and reduces the possibility of transporting contaminated water across the interbed. 


\section{EXECUTIVE SUMMARY}

The Facilities and Maintenance Landlord at the Technical Support Facility (TSF) at Test Area North (TAN) has proposed that a new potable well be provided by the Landlord Program in support of TAN activities. Detection of trichloroethylene (TCE) and bacterial contamination in the present drinking water system has, at times, rendered it unacceptable for use. The TCE forms a plume in the ground water with highest concentrations detected near the injection well (TSF-05). The first objective in constructing a new drinking water well is to identify a well site with a high probability of being contaminant free. Investigation of a new well site will enable project planning and development to proceed in a more focused and cost effective manner.

The purpose of this study is to utilize the best available information for evaluating various locations for siting the new well in close proximity to TAN. Results of this study include analyses of four scenarios based on three different well locations and a different well completion to make a recommendation for a safe site for the new well. The following factors were considered in analyzing potential locations:

1) data indicating the area encompassed by the TCE plume,

2) capture zone for the proposed wells,

3) how the above factors will be effected over time, and

4) the physical characteristics of the aquifer.

It is assumed for the purposes of this study, that there are no unknown contaminants at the proposed well locations.

Computer simulations were performed to identify a safe location for the proposed well. The modeling effort involved:

1) producing a water table map,

2) superimposing the pumping effects from each proposed well location on the water table using the CAPZONE model,

3) calculating the capture zone for each well scenario using the GWPATH model, and

4) evaluating the siting of a new well in a deeper horizon in the aquifer using a three dimensional flow model.

The following four scenarios were investigated: (1) placing a new well about 500 feet north of the existing wells, completed about 350 feet below 1 and surface; (2) locating a well about 3000 feet northwest of the existing wells, also completed about 350 below land surface; (3) deepening one of the existing wells from about 350 feet to about 600 feet below 1 and surface to produce water from beneath the $Q-R$ interbed which acts as a hydraulic barrier; and drilling a well about $500 \mathrm{ft}$ northeast of the existing wells to a depth of about 600 feet to produce water from beneath the $Q-R$ interbed. This study recommends the location of the well presented in the fourth scenario. 


\section{CONTENTS}

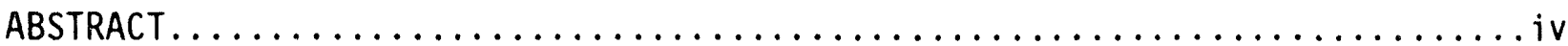

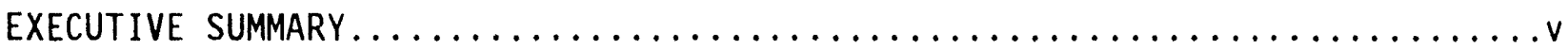

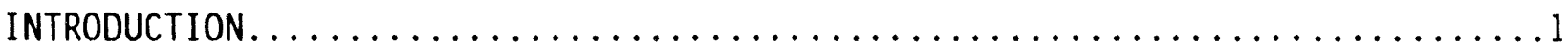

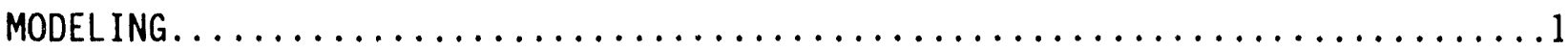

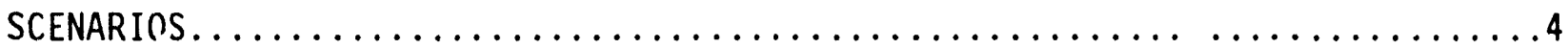

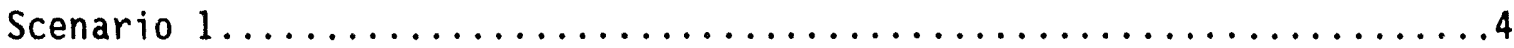

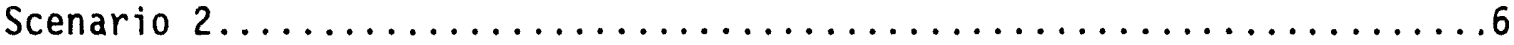

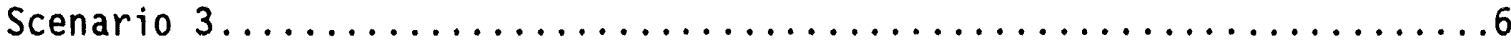

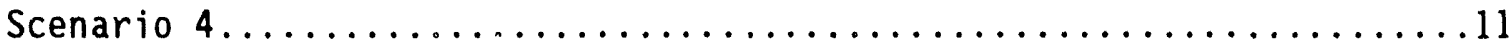

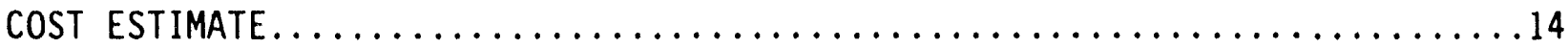

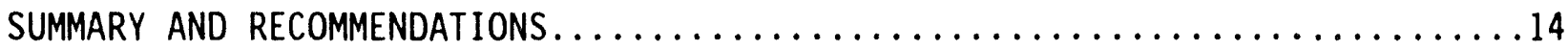

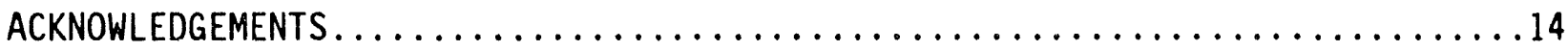

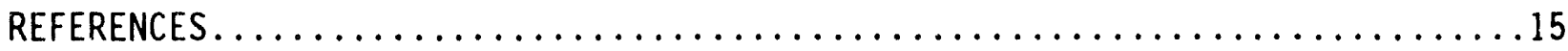

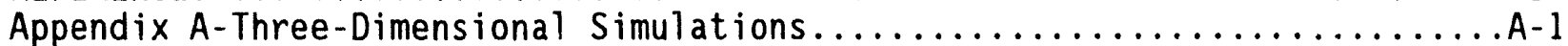

Appendix B-Estimated Cost of Drilling a 20 inch Diameter We11..............

Appendix C-Copies of Color Overhead Transparencies.....................

\section{FIGURES}

1. Plan view of Test Area North with wells and TCE ground water plume,

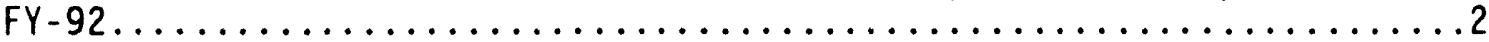

2. Scenario 1. Five year capture zone for proposed TAN well located $500 \mathrm{ft}$

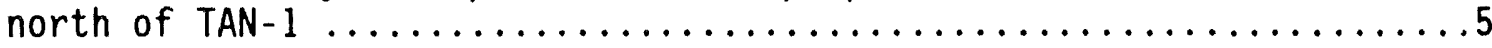

3. Scenario 2. Five year capture zone for proposed TAN well located

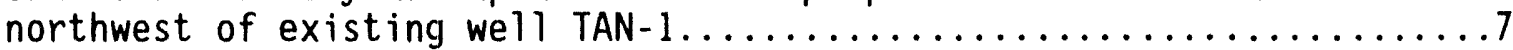

4. Scenario 2. Ten year capture zone for well located northwest of wells

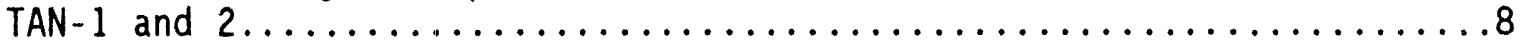

5. Scenario 3. Cross section with TAN-1 deepened below the Q-R interbed...9

6. Scenario 3. Location of geologic cross section $B-B^{\prime} \ldots \ldots \ldots \ldots \ldots$

7. Scenario 4. Recommended location of new potable water supply well for

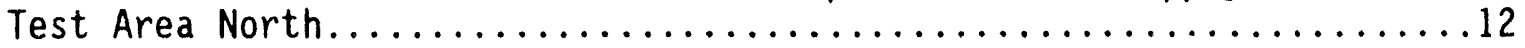

8. Scenario 4. Cross section with proposed new well screened below the $Q-R$ interbed. 


\title{
SITING STUDY FOR TEST AREA NORTH POTABLE WATER DEEP WELL PROJECT
}

\author{
FY-94 LL GPP
}

\section{INTRODUCTION}

This study was conducted to evaluate the suitability of several locations for a new potable ground water well at Test Area North (TAN) using capture zone and three dimensional numerical analyses. The Facilities and Maintenance Landlord at TAN has proposed a new potable well be provided by the Landlord Program. Water obtained from the current water supply wells (TAN-1 and TAN-2) has had concentrations of trichloroethylene (TCE) that have exceeded the U.S. 1. A primary drinking water standards maximum contaminant level's (MCL's) at : $a$ well heads. An air sparging system treats the water prior to use reducing the TCE concentrations to acceptable levels (Kaminsky et al., 1993). A new well is needed to provide potable water that is free of contaminants and does not require treatment prior to use. Modeling was performed to assist in determining an acceptable location for a new water supply well.

An undetermined volume of organic (TCE), inorganic, and low-level radioactive wastewaters mixed with nonhazardous process and sanitary wastewaters were disposed of in the $305 \mathrm{ft}$ deep, TSF-05 injection well from 1953 to 1972. Ground water sampling in 1987 confirmed the presence of TCE in the water system at TAN. Figure 1 presents a location map showing the TCE plume and drinking, monitoring and injection wells at TAN.

The TCE ground water plume covers a large portion of TAN (Figure 1), which limits the possible locations for a replacement well. The TSF-07 sewage disposal pond at the Technical Support Facility (TSF) may also affect the location of a new water supply well (Figure 1). Additional data on disposal practices and site characteristics in the TSF area can be found in the draft Remedial Investigation Final Report with Addenda for the Test Area North Groundwater Operable Unit at the Idaho National Engineering Laboratory Volume 1, February 1993 (Kaminsky, et al., 1993).

\section{MODELING}

This section presents information on the hydrologic parameters, code description and scope of work for capture zone analyses performed in siting a proposed TAN production well.

Capture zone modeling defines the region surrounding the well that contributes water to the well over a specified time period for a given pumping rate. Capture zone simulations were performed using five or ten year periods. Capture zones are based on advective ground water flow velocities and do not account for chemical or biological attenuation, dispersion or diffusion. The modeling technique used assumes homogeneous and isotropic aquifer properties. 


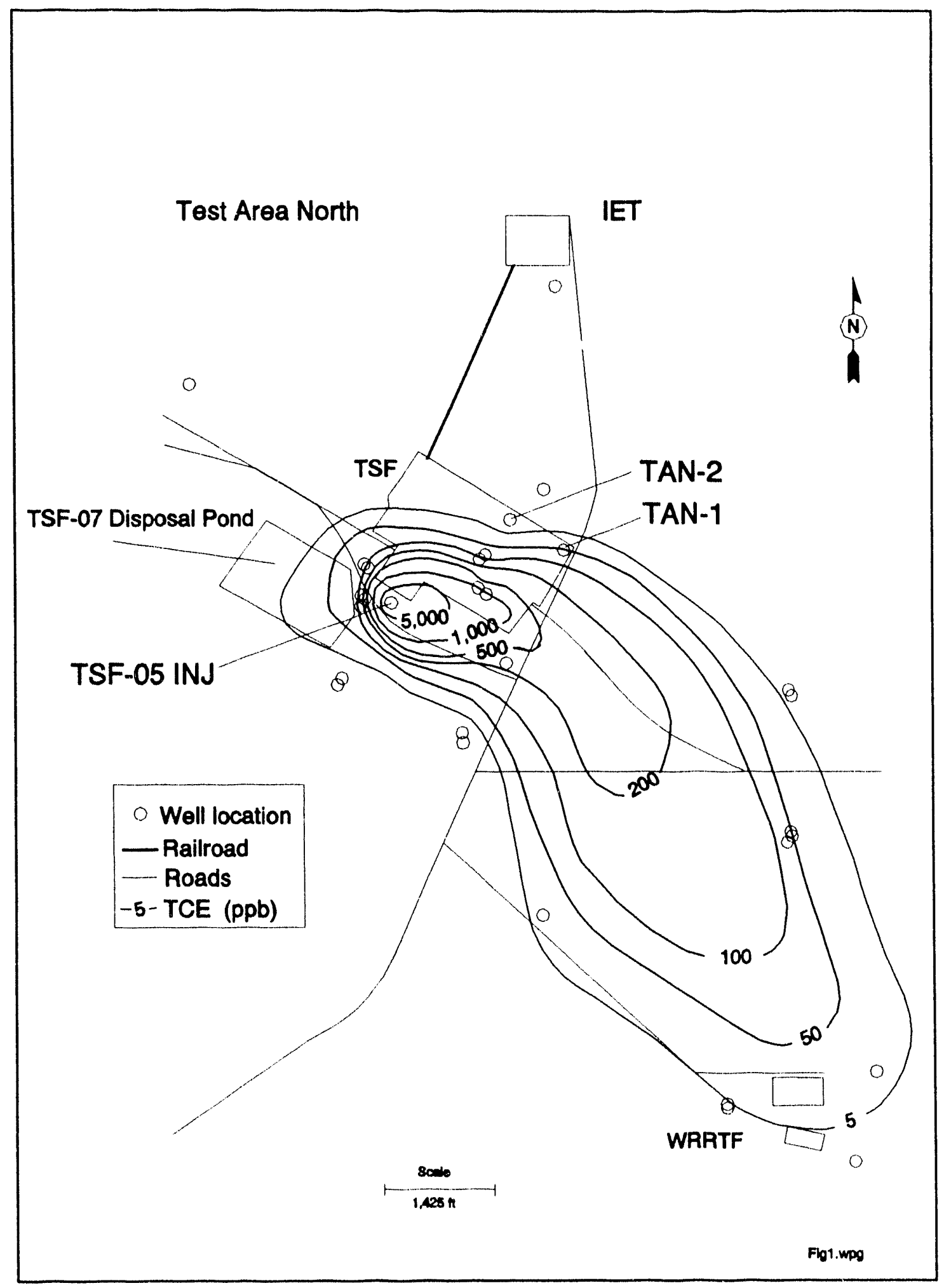

Figure 1. Plan view of Test Area North with wells and TCE ground water plume, FY-92. 
The computer programs used to evaluate the capture zone for the proposed action at TAN included:

SURFER A graphics program by Golden Software, Inc. of Golden, Colorado was employed for contouring data. It produces customized contour maps using either gridded or randomly scattered data. SURFER waS used to develop water table contour maps that were input to CAPZONE.

CAPZONE An analytical flow model by E. Scott Bair et al. (1991) for simulating transient, two-dimensional flow to wells in fullyconfined, leaky-confined, or unconfined aquifers. CAPZONE can import gridded water table files from SURFER and superimpose the effects of both pumping and reinjecting water. This program simulated the effects of pumping water from selected production well locations.

GWPATH A two-dimensional particle-tracking program by J. M. Shafer (1987). GWPATH was used to track pathlines and delineate travel time and capture zones for the proposed production well locations.

The modeling effort involved the following steps: 1) a water table map was developed using SURFER, 2) the effects of pumping the proposed production well were superimposed on the SURFER map using CAPZONE, and 3) the capture zone for these wells was calculated using GWPATH. Resultant data were imported into Freelance and DrawPerfect to generate the figures.

Several assumptions were made during the evaluation, including:

- capture zones were evaluated for a well pumping at 45 million gallons per year $(123,000 \mathrm{gpd}$ or $85 \mathrm{gpm})$. The average pumping rate at TAN is 35 to 45 million gallons per year (personal communication with Tom Trace) so the high average was used in the simulations to provide conservative capture zone estimates. The two pumps in wells TAN-1 and TAN-2 are each able to pump approximately 1000 to 1500 gallons per minute,

- the ground water monitoring data obtained during the TAN Remedial Investigation adequately delineates the existing contaminant plume, and

- no unknown contaminated sites exist near TAN.

Hydraulic properties of the Snake River Plain aquifer beneath the INEL vary widely over short distances. This is because aquifer permeability is controlled by the distribution of highly fractured basalt flow tops and interflow zones with some additional permeability contributed by fractures, vesicles and intergranular pore spaces. It is necessary to select representative hydraulic properties for input into the analytical programs to achieve accurate estimates for well design and site selection.

Ackerman (1991) analyzed aquifer test data from 183 single-well tests at 94 wells in the Snake River Plain aquifer to calculate values of transmissivity. Four of these wells (TAN-1, TAN-2, USGS-24, and the TSF-05 Injection well) are 
in the vicinity of the TAN site. The aquifer test of the TSF-05 injection well was conducted 33 years after the well was first used for waste disposal. Thus, the transmissivity vaiues from this test may not be representative of the aquifer because particles of waste could have plugged many of the pores in the aquifer adjacent to the well. Thus, the transmissivity value from the TSF-05 injection well was not used. The transmissivity values for the remaining wells, TAN-1, TAN-2, and USGS-24, are 29,000, 16,000, and 14,000 $\mathrm{ft}^{2} /$ day, respectively. Both CAPZONE and GWPATH call for a hydraulic conductivity value, which is calculated by dividing the transmissivity by the saturated thickness encountered in the well. The hydraulic conductivity obtained in this manner for TAN-1, TAN-2, and USGS-24 are all $200 \mathrm{ft} / \mathrm{day}$ when rounded to one significant figure. Thus a hydraulic conductivity of 200 $\mathrm{ft} / \mathrm{day}$ was used in these simulations.

Aquifer porosity is a required input parameter for the CAPZONE and GWPATH models. A porosity of $10 \%$ (Robertson et. al., 1974) was used in the simulations. Water level elevation data for the TAN area were used from January, 1993 field measurements.

\section{SCENARIOS}

Four scenarios were investigated for siting a new water supply well at TAN. The first scenario involved placing a new well $500 \mathrm{ft}$ north of well TAN-1; the second scenario involved locating the well at a site where pumping would not produce water from the TCE plume within 5 years (while avoiding other potential contaminant sources); the third scenario involved deepening well TAN-1 to beneath a sedimentary interbed that is a hydraulic barrier and the fourth scenario involved drilling a new well north of TAN-1 and TAN-2 to produce water from beneath the sedimentary interbed.

The analytical process outlined above provides a reasonable estimate for the size of the capture zone of the proposed production well. Several simplifying assumptions were made for these calculations and deviation from the idealized case may cause the actual capture zone to vary from those calculated. The shape of the capture zone and the lncation of flow paths calculated by GWPATH may vary slightly depending upon location of the well within the model's grid network.

\section{Scenario 1}

Figure 2 presents the simulation where the proposed new TAN pumping well is located $500-\mathrm{ft}$ north of TAN-1. The 5 year capture zone is shown as the shaded area in Figure 2. Most of the water in this simulation comes from up-gradient and out of the TCE plume, but a significant portion of the water also comes from south and west of the new well. A portion of the water comes from the ground water mound to the west of the new well formed from water disposed in the TSF-07 disposal pond. It should be noted that the TSF-07 disposal pond will be used in the next 1 to 10 years for disposal of treated water from remediation efforts at the TSF-05 injection well. This simulation (and 


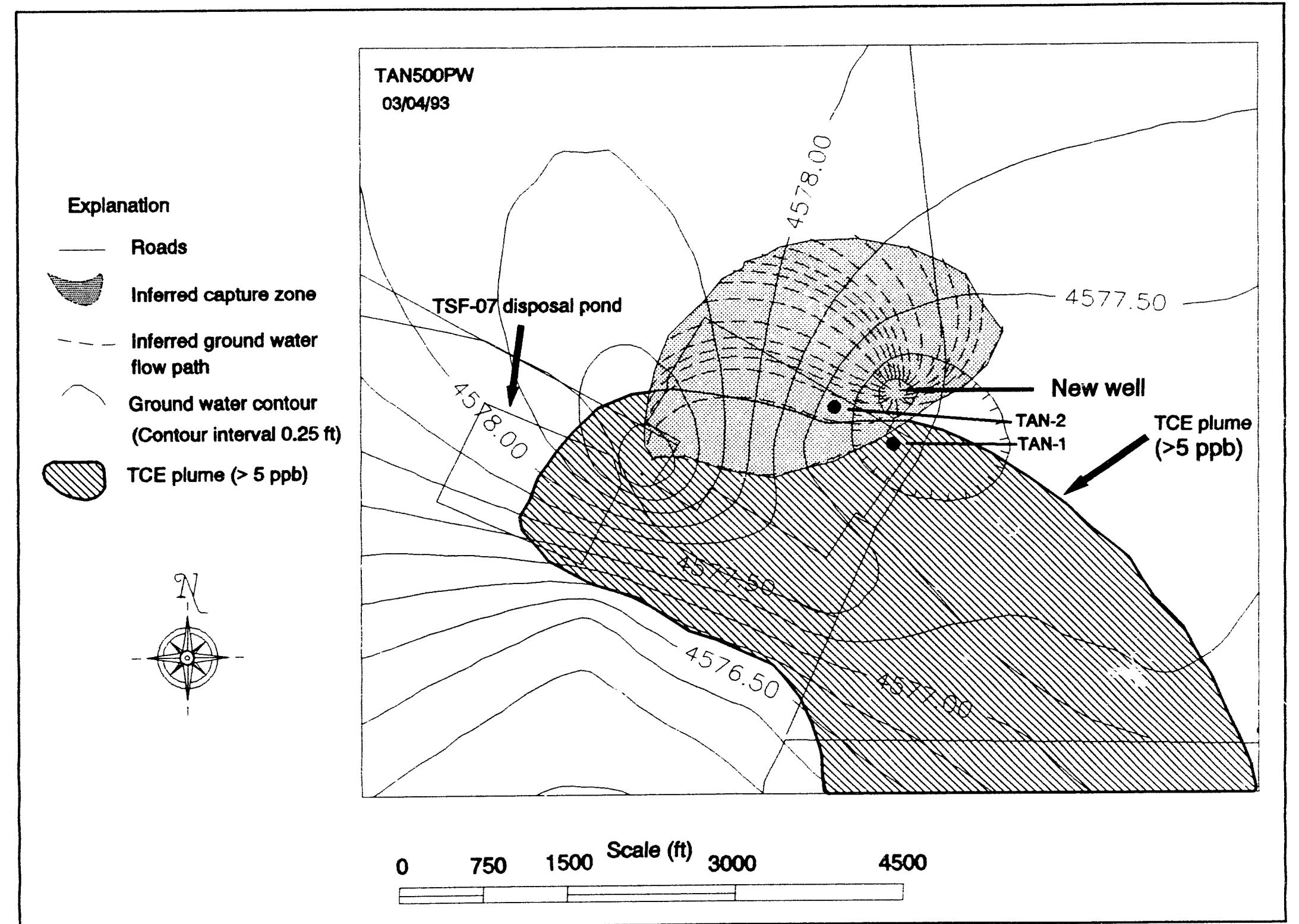

Figure 2. Scenario 1. Five year capture zone for proposed TAN well located $500 \mathrm{ft}$ north of TAN-1. 
subsequent simulations) indicate recharge from this pond would contribute water to a new production well located near the TSF.

The outline of the $5 \mathrm{ppb}$ TCE iso-concentration of the TAN ground water plume is shown in Figure 2 along with the 5 year capture zone. The $5 \mathrm{ppb}$ TCE iso-concentration line defines the area where water in the aquifer exceeds the MCL for TCE.

Overlap of the 5 year capture zone and the contamination plume indicates a portion of the water produced in this proposed well will come from the TCE ground water plume. Therefore, this proposed location is not ideal and a second potential site for the TAN potable drinking water well was evaluated.

\section{Scenario 2}

A second site was located by examining the potential contamination sources at TAN, placing it out of the direct influence of those sources while locating the well as near as possible to the TSF. The TAN ground water plume is located south and east of TAN so this area was eliminated from consideration. The closest potential site for a new well is northwest of TAN, upgradient of the TCE ground water plume. A site $1500-\mathrm{ft}$ north and $750-\mathrm{ft}$ west of the northwest corner fence line at TAN was chosen for this evaluation. This site is approximately $3700 \mathrm{ft}$ northwest of the production well TAN-1.

Two simulations were performed with capture zones for five and ten years. The five year capture zone simulation is presented in Figure 3 . The shaded area surrounding the new well shows the area where water would be obtained during the five year pumping period. The 5 year capture zone does not overlap with the TAN TCE ground water plume. Much of the water is obtained from the mound formed from recharge from the TSF-07 Disposal Pond.

The ten year capture zone indicates the cafture zone overlaps the TCE plume (Figure 4). The greater distance to this proposed site from TSF would significantly increase costs and would not ensure the water would be completely contaminant free over the 10 year period. Since the proposed replacement well for TAN-1 will probably be used for 10 or more years, this proposed location is also not ideal and a third scenario was considered.

\section{Scenario 3}

Alternate approaches were evaluated due to the added expense of dri?ling and constructing a new water supply well outside the influence of the TCE plume to ensure clean water. Wells TAN-1 or TAN-2 could be deepened so water is obtained from beneath the Q-R interbed and beneath the TCE plume. The usefulness of this scenario depends upon how effective the sedimentary interbed is in preventing contaminated water from moving into the lower basalt layers. A north-south geologic cross section beneath the TAN area showing well TAN-1 deepened to obtain water from below the Q-R interbed along with the location of the TCE plume is presented in Figure 5. The location of the cross section is shown in Figure 6 . 
Explanation

Roads

Roads
Inferred capture zone

- Inferred ground water flow path

Water table contour (Contour interval $0.25 \mathrm{ft}$ )

TCE plume (>5 ppb)
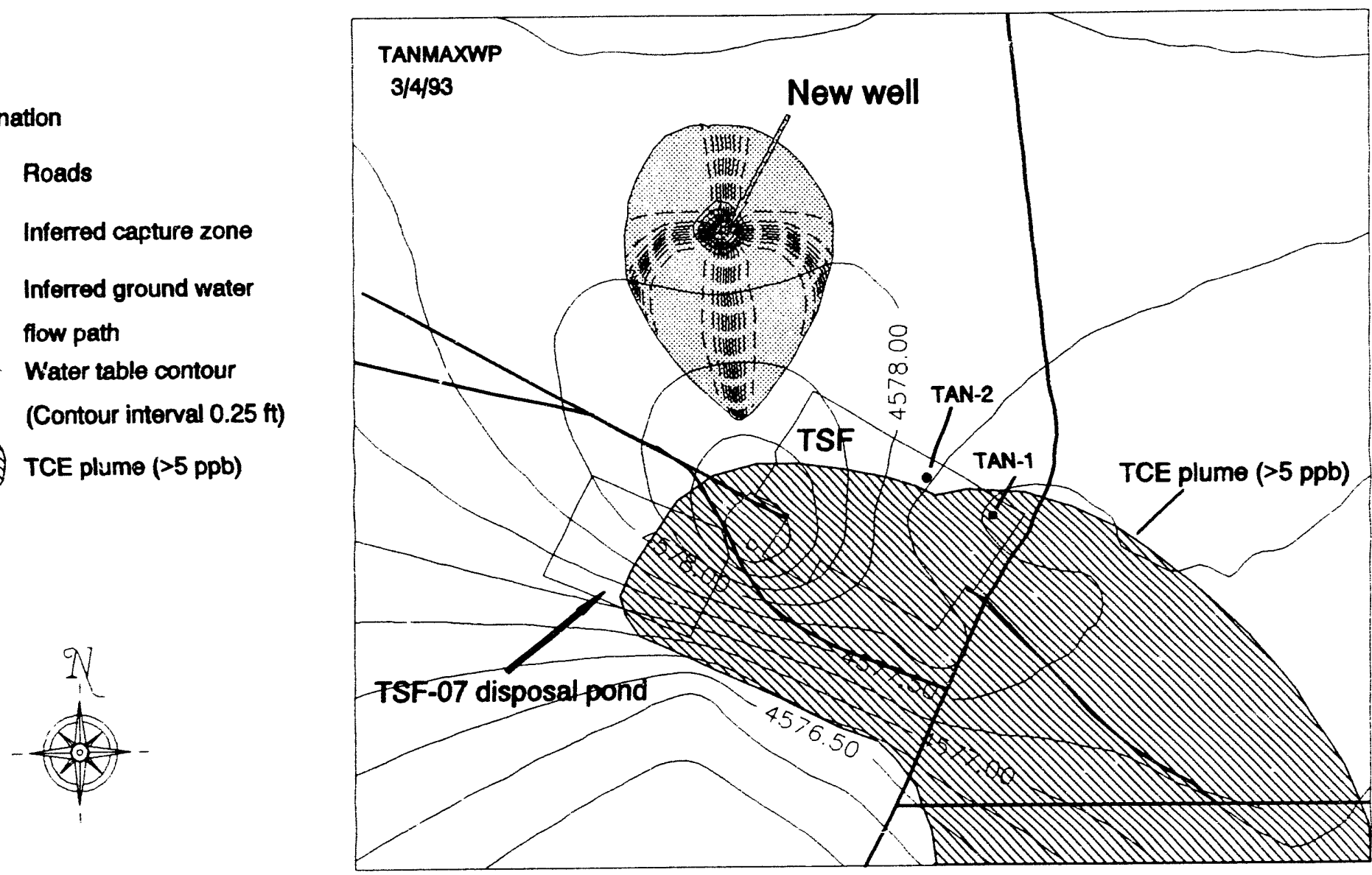

Scale (ft)

$\begin{array}{llll}0 & 750 & 1500 & 3000\end{array} 4500$

Figure 3. Scenario 2. Five year capture zone for proposed TAN well located northwest of well TAN-1. 


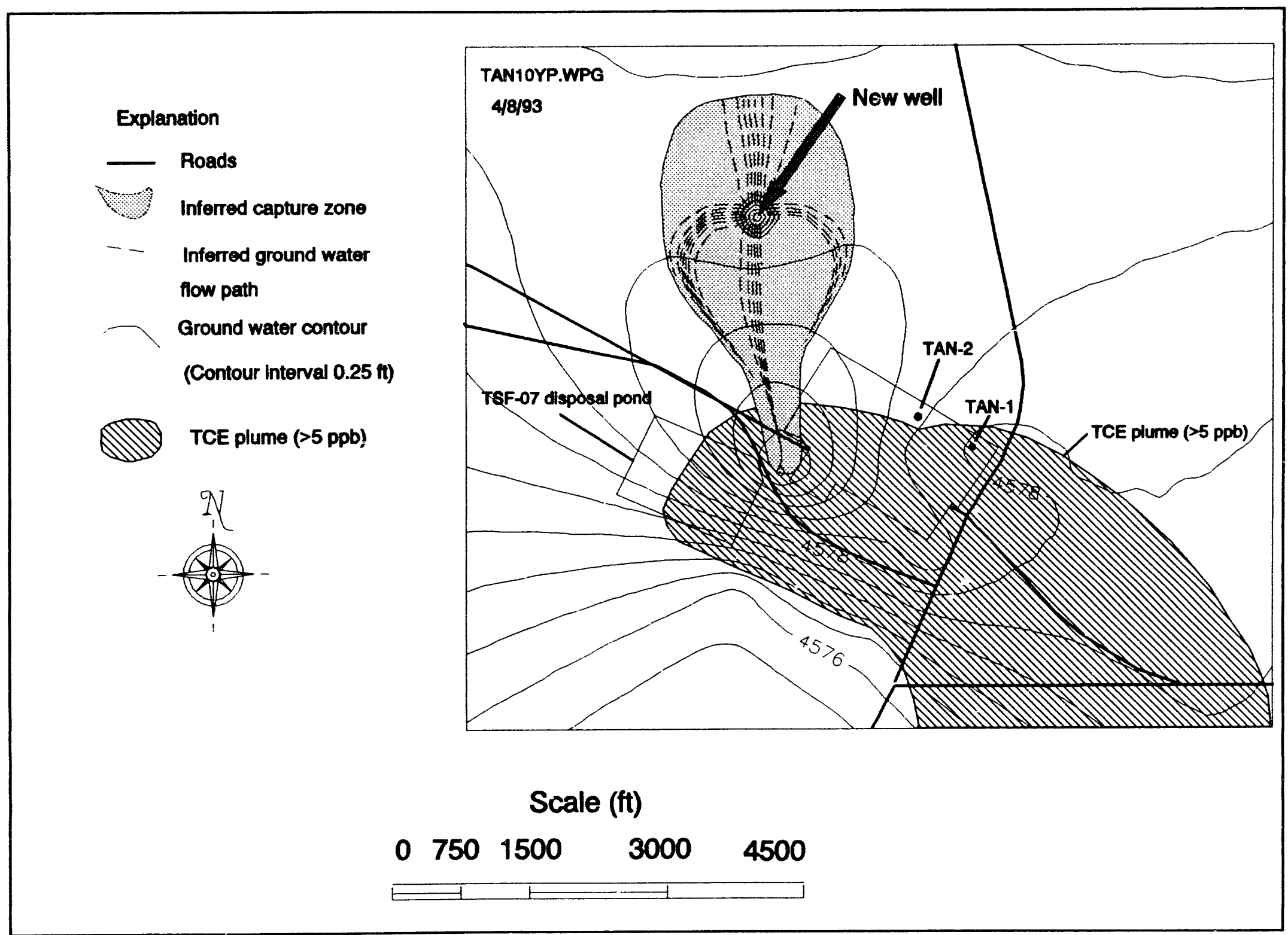

Figure 4. Scenario 2. Ten year capture zone for well located northwest of wells TAN-1 and -2 . 


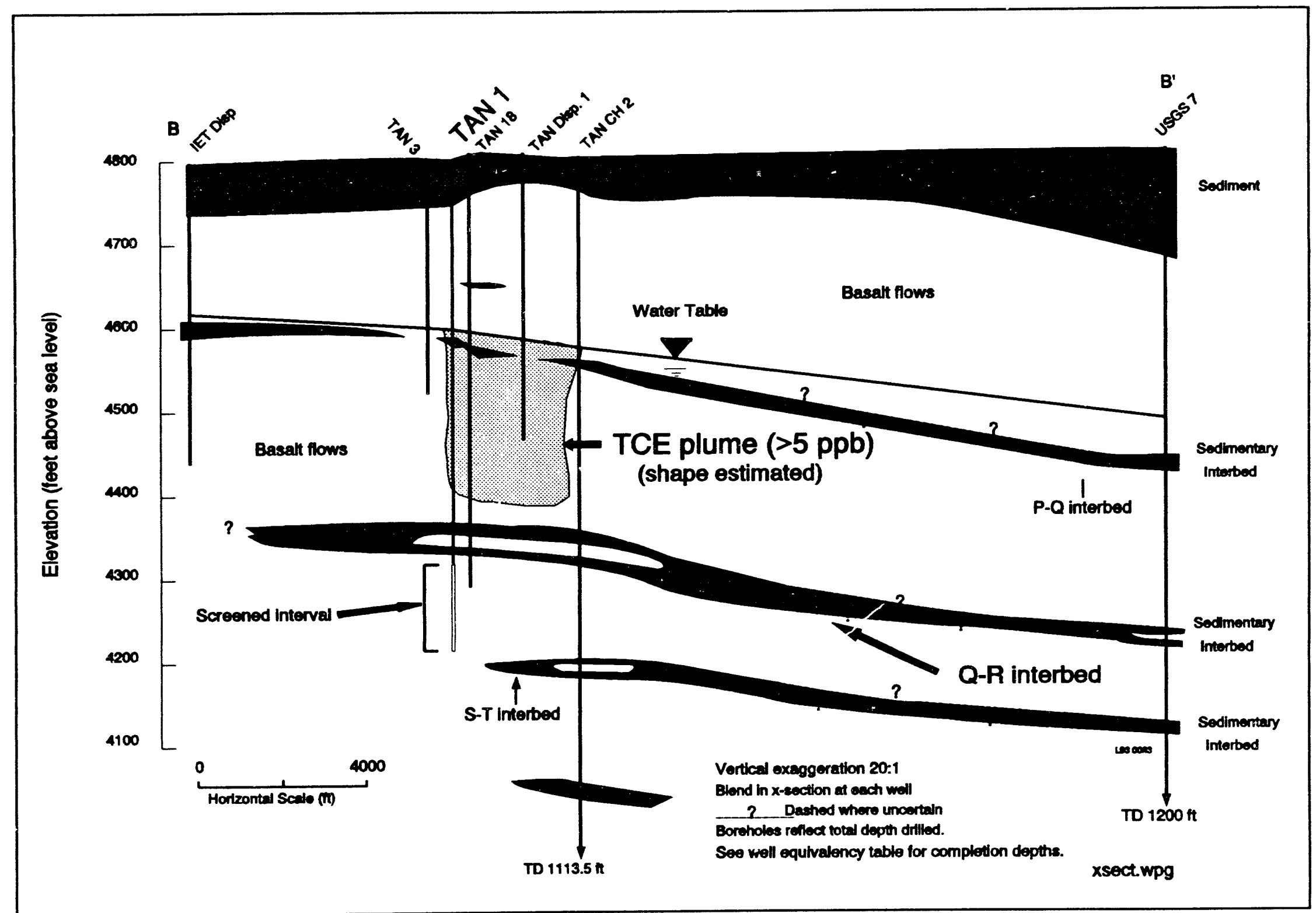

Figure 5. Scenario 3. Cross section with TAN-1 deepened below the Q-R interbed. 


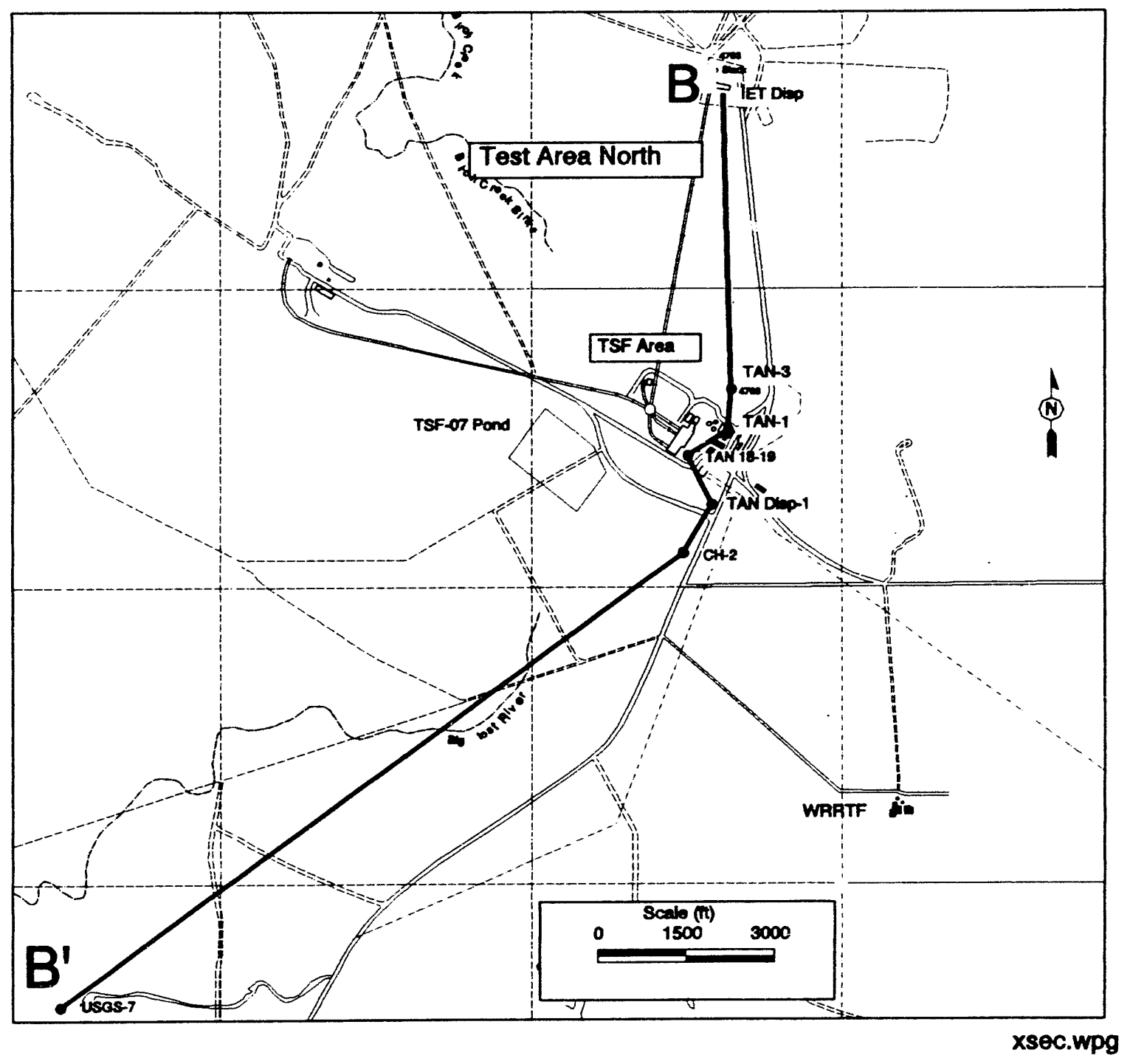

Figure 6. Scenario 3. Location of geologic cross section $B-B^{\prime}$. 
Monitor wells completed beneath the Q-R sedimentary interbed indicate TCE has not migrated below this interbed (Kaminsky et al, 1993). Core samples from the $Q-R$ interbed indicate a vertical saturated hydraulic conductivity of $2.8 \times$ $10^{-1}$ to $1.0 \times 10^{-3} \mathrm{ft} /$ day. The range of transport times across the interbed is calculated to be from $2.4 \times 10^{-1}$ to $9.0 \times 10^{-4} \mathrm{ft} /$ day based on Darcy's Law, assuming a $5 \mathrm{ft}$ thick interbed (range is 5 to $30 \mathrm{ft}$ ), $1.5 \mathrm{ft}$ of head difference across the interbed, and a porosity of $35 \%$. Water is calculated to "...ve across the $5 \mathrm{ft}$ thick interbed in approximately three months using the iservative estimates of the transport parameters. We1ls TAN-1 and TAN-2 are esently located within the TCE plume, so if either well were deepened it would have the potential to draw contaminants from the overlying TCE plume into the well in a few months. This proposed location is not recommended and a fourth scenario was evaluated.

\section{Scenario 4}

Scenario 4 combines drilling a new well north of the TCE plume and completing the well so water is obtained from below the Q-R interbed. Locating a new well north of TAN-1 and TAN-2 (near TAN-3) will place the well outside the influence of the TCE plume (Figure 1). The proposed well would be completed below the Q-R interbed between 500 to $6,00 \mathrm{ft}$ below land surface. Figure 7 presents the proposed location of a new potable water supply well for TAN while Figure 8 presents a cross section of the proposed location. This location provides a margin of safety by isolating the well from the plume both vertically and horizontally. The well location is north of the TCE plume, close to the TSF fence line, and between the railroad tracks and the road to IET. The well would be drilled to about $600 \mathrm{ft}$ (dependant upon stratigraphy and hydrology) and the upper portion of the well sealed so water is obtained from beneath the $Q-R$ interbed. This portion of the aquifer does not have TCE and recent pumping tests have indicated that the interbed is an effective hydraulic barrier in preventing contaminants from moving downward into lower basalt layers (Kaminsky et al., 1993). Placing the new water supply well at this location will allow the TCE plume to shift more toward the south over time since wells TAN-1 and TAN-2 would not be operating.

This scenario was evaluated using a three dimensional ground water model coupled with a contaminant transport code. This evaluation indicated that a well drilled northwest of the existing production wells (shown in Figure 7) would not obtain water from the TCE plume over a 20 year time period. Appendix $A$ contains a description of the model, modeling assumptions and results which support the conclusion of locating the proposed production well as described in this scenario.

The well size, pump size and pumping rate of the new well should be determined by the peak use and storage capabilities of water at this facility. The pump size could be reduced to supply $500 \mathrm{gal} / \mathrm{min}$ which would reduce overall costs for equipment and save electrical costs. To comply with other regulations for fire protection, either the TAN-1 or TAN-2 well could be kept on line to supply large volumes of water for emergencies. Chemical analyses from well TAN-18 indicate that the water below the $Q-R$ interbed is suitable as drinking water (Kaminsky et al., 1993). 


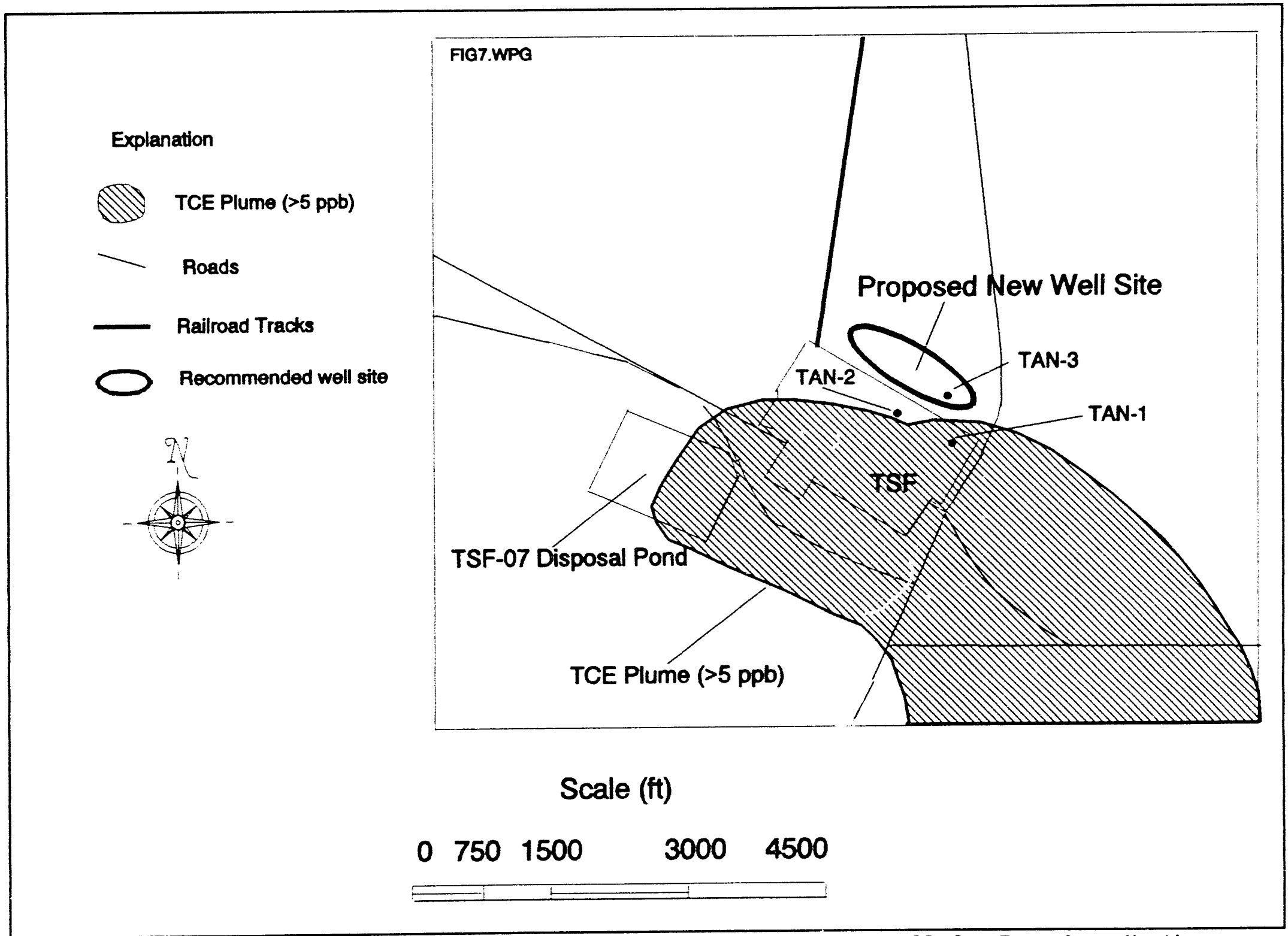

Figure 7. Scenario 4. Proposed location of a new potable water supply well for Test Area North. 


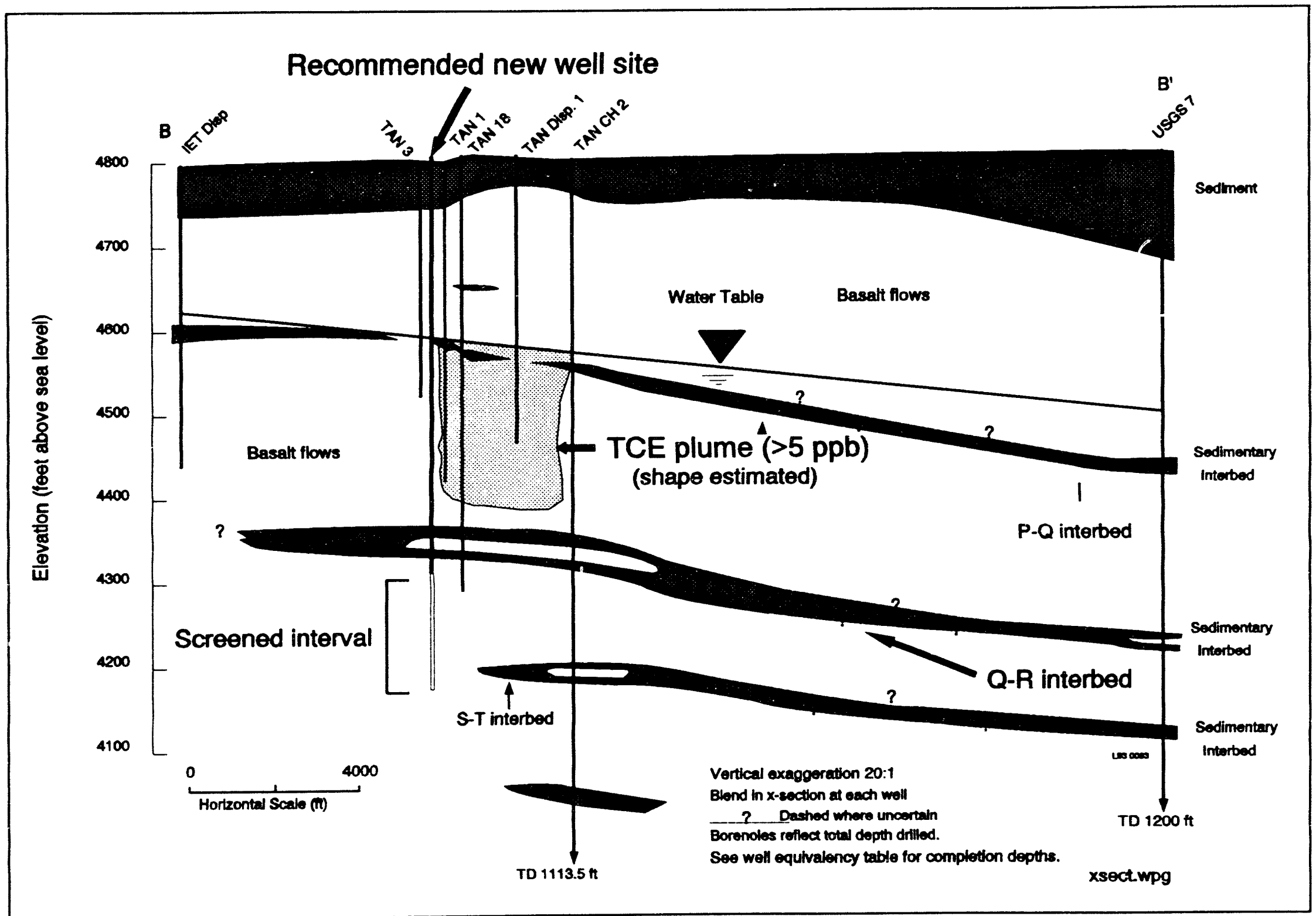

Figure 8. Scenario 4. Cross section with proposed new well screened below the Q-R interbed. 


\section{COST ESTIMATE}

A cost estimate for drilling and completing a new 20 inch diameter well at this site is approximately $\$ 180,000$ (Appendix B). This estimate includes the drilling subcontractor costs, but not costs for a new building, power, piping and other associated costs.

The cost savings in drilling a new deeper well northwest of TAN-l compared to siting a well so the plume is out of the capture zone in the upper portion of the aquifer should be significant. Reducing the distance to the new water supply well will reduce construction costs for bringing in power, and piping the water from a more distant location, along with reducing costs for NEPA documentation and archeological clearance. These costs could run into the hundreds of thousands of dollars.

\section{SUMMARY AND RECOMMENDATIONS}

Capture zone analyses were performed to determine a recommended site for a new drinking water well at TAN. Results indicate a new well should be located north of the TAN-1 and TAN-2 production wells and drilled to approximately 600 $\mathrm{ft}$ to produce water from beneath the $Q-R$ interbed. Locating the well north of the existing wells places the new well out of the TCE plume and reduces the possibility of transporting contaminated water across the interbed. This scenario was evaluated with a three dimensional ground water model coupled with a solute transport code. The modeling indicated that pumping at this location will not obtain water from the TCE plume for at least 20 years and the TCE plume will begin to move away from the new well.

\section{ACKNOWLEDGEMENTS}

The authors wish to thank Joanne Knight for her advice and guidance on this project. The authors also wish to thank Mike Shook for conducting the three dimensional modeling. Mention of specific products and/or manufacturers in this document implies neither endorsement of preference nor disapproval by the U.S. Government, any of its agencies, or EG\&G Idaho Inc. of the use of a specific product for any purpose. 


\section{REFERENCES}

Ackerman, D. J., 1991, "Transmissivity of the Snake river Plain Aquifer at the Idaho National Engineering Laboratory, Idaho," Water-Resources Investigations Report 91-4058, U.S. Geological survey, p. 35.

Bair, E. S., A. E. Springer, and G. S. Roadcap, 1991, "Delineation of traveltime-related capture areas of wells using analytical flow models and particle-tracking analysis," Ground Vater, Vol. 29, No. 3, pp. 387398.

Kaminsky, et. al., 1993, Remedial Investigation Final Report with Addenda for the Test Area North Groundwater Operable Unit at the Idaho National Engineering Laboratory Volume 1, February 1993 (Draft). EGG-ER-10643.

Robertson, J. B., R. Shoen, J. T. Barraclough, 1974, "The influence of liquid waste disposal on the geochemistry of water at the NRTS, Idaho: 19521970," IDO-22053, p. 231

Shafer, J. M., 1987. "GWPATH: interactive ground-water flow path analysis," Bulletin 69, Illinois State Water Survey, Champaign, I1linois, p. 42. 
APPENDIX A

THREE-DIMENSIONAL SIMULATIONS

A-1 


\section{Appendix A. Three-Dimensional Simulations}

A three-dimensional computer simulation study was undertaken to evaluate the likelihood of producing TCE-contaminated water from a proposed new water well at TAN. This new well is modeled to be completed at a greater depth than the two existing water wells it will replace, and beneath the contaminated interval. This study addresses the concern of TCE moving through the $Q-R$ interbed and into the proposed new well.

The simulator used in this study is TETRAD (Vinsome and Shook, 1993). TETRAD is a fully implicit, three dimensional finite difference simulator capable of solving the mass conservation equations that describe flow in porous media. It has been validated against a number of different problem types, including oilfield applications (Vinsome, 1990) as well as transient pressure problems (Shook and Faulder, 1991).

The study area is shown in Figure Al. The zone of interest was simulated as three homogeneous, isotropic units: the upper basalt, the $Q-R$ interbed, and the lower basalt. Hydraulic properties for each layer are consistent with measured values, and are given in Table A1. Use of isotropic properties is probably conservative, because in depositional environments horizontal hydraulic conductivity is typically larger than the vertical, and fluid therefore has a greater tendency to flow horizontally. Use of isotropic properties should give conservative estimates of vertical contaminant transport.

Table A1. Summary of Hydrogeologic Properties Used.

\begin{tabular}{|l|l|l|l|}
\hline Property \Layer & Basalt Layer 1 & Q-R Interbed & Basalt Layer 2 \\
\hline Thickness & $200 \mathrm{ft}$. & $20 \mathrm{ft}$. & $200 \mathrm{ft}$. \\
\hline Porosity & 0.1 & 0.34 & 0.1 \\
\hline $\begin{array}{l}\text { Hydraulic } \\
\text { conductivity }\end{array}$ & $200 \mathrm{ft} / \mathrm{d}$ & $0.31 \mathrm{ft} / \mathrm{d}$ & $200 \mathrm{ft} / \mathrm{d}$ \\
\hline
\end{tabular}

The contaminant was simulated as an aqueous tracer. The tracer was constantly replenished via injection at the location of the former injection we 11 (TSF-05), simulating a source of TCE. The true source of the contamination is an immobile phase of TCE that partitions slowly into the aqueous phase.

The maximum solubility of TCE in water is $1100 \mathrm{mg} / \mathrm{T}$ (Feenstra et al., 1991), which can be expressed as either a weight fraction or mole fraction as

$$
\begin{aligned}
& \left(1100 \times 10^{-3} \mathrm{~g} / \mathrm{l}\right)\left(11 \mathrm{H}_{2} \mathrm{O} / 1000 \mathrm{~g}\right)=1.1 \times 10^{-3} \mathrm{~g} \mathrm{TCE} / \mathrm{g} \mathrm{H} \mathrm{O} \\
& \star(1 \mathrm{~mol} \text { TCE } / 131.3 \mathrm{~g})\left(18.02 \mathrm{~g} \mathrm{H} \mathrm{H}_{2} / \mathrm{mol}\right) \\
& =1.51 \times 10^{-4} \mathrm{~mol} \mathrm{TCE} / \mathrm{mol}_{2} \mathrm{O}
\end{aligned}
$$

The simulated contaminant (the aqueous tracer) is injected at a mole fraction of 1 ; therefore, simulated mole fractions must be multiplied 
by $1.51 \times 0^{-4}$ to reflect true TCE mole fractions. This normalization provides ti.e ability to simulate TCE concentrations down into the 5 parts-per-billion ( $5 \mathrm{ppb}$ ) range, considered to be the lower level of interest. TETRAD uses mole fractions internally, however, these can be converted to conventional units using the following identities:

$$
\begin{aligned}
& 5 \mathrm{ppb}=5 \times 10^{-9} \mathrm{~g} \mathrm{TCE} / \mathrm{g} \mathrm{H}_{2} \mathrm{O} \\
& \text { * (1 mol TCE / } 131.3 \mathrm{~g})\left(18.02 \mathrm{~g} \mathrm{H} \mathrm{O}_{2} / \mathrm{mol}\right. \text { ) } \\
& =6.86 \times 10^{-10} \mathrm{~mol} \mathrm{TCE} / \mathrm{mol} \mathrm{H}_{2} \mathrm{O}
\end{aligned}
$$

Hydraulic properties of water at these levels of contamination differ negligibly from those of pure water, and therefore pure water

properties were used in the study. Adsorption of the contaminant was not considered.

The simulation proceeded as follows. The northern and southern boundaries were held at constant head, so that a hydraulic gradient of $0.0002 \mathrm{ft} . / \mathrm{ft}$. ( $1.1 \mathrm{ft} . / \mathrm{mile})$ was established across the study area. The other boundaries were treated as no-flow. The system was allowed to equilibrate for a period of time, so that pressure distributions across the study area were consistent with observed pressures (converted from potentiometric surfaces). After equilibration, the two existing water wells began pumping. Each well was maintained at a rate of $60,000 \mathrm{gal} / \mathrm{d}$. Beginning at the same time, the tracer was injected at a rate of $250 \mathrm{gal} / \mathrm{d}$, although this rate was varied in some

sensitivity runs. After 20 years of pumping, the two wells were shut off, and a new we 11 began pumping. The location of the new well is given in Figure $A 1$. This well was maintained at a pumping rate of $123,000 \mathrm{gal} / \mathrm{d}$, replacing both of the other wells. The time frame of interest for the new we 11 was 20 years of additional pumping. The time frame of interest ranges from 20 years of previous pumping to 20 years of future pumping. Therefore, simulated time ranges from year 1973 2013.

Results of the simulation are given in Figures $A 2-A 5$. Figure $A 2$ shows the contamination profile in the top layer (above the $Q-R$ interbed) just before the two existing wells are replaced (year 1993). The concentration plume is qualitatively as is observed, with TCE concentrations at TAN-1 in excess of $10 \mathrm{ppb}$ and no TCE observed at TAN2. The plume moves down-gradient, as expected.

Figure $A 3$ shows tracer concentrations below the $Q-R$ interbed, again at $t=1993$. The maximum tracer concentration in this layer is approximately $500 \mathrm{ppb}$; however, this concentration is appreciably further south than the plume in the upper basalt. These concentrations represent a conservative estimate for two reasons. First, adsorption of the tracer was neglected in this study. Adsorption would trap a significant amount of the mobile tracer in the $Q-R$ interbed, thus restricting the concentration below the interbed. Also, the horizontal hydraulic conductivity used was set equal to the vertical in the interbed. This enhances the fluids' tendency to move vertically, and therefore more crossflow is present in the simulations than probably 
occurs. This approach was adopted in this study to remain conservative on the issue of potable water contamination.

The final two figures show tracer concentrations after pumping the new well for 20 years $(t=2013)$. Figure A4 shows concentrations in the upper basalt. As before, TAN-1 remains within the contamination plume, with TCE concentrations near $50 \mathrm{ppb}$. The proposed new well remains outside the Ti: plume throughout the 20 year simulation. The upper basalt has the largest contamination plume, as the source is located in this layer. No tracer is found upstream (north) of the simulated source location (TSF-05), even in the layer with the largest contamination. This suggests the likelihood that the proposed new well would remain uncontaminated.

Figure $A 5$ shows tracer concentration profiles just below the $Q-R$ interbed, twenty years after opening the new well. While there is measurable tracer in this layer, it is several thousand feet south of the new well. Again, no tracer is found within 3000 feet of the new well at the screened interval. Simulated water production from the new we 11 also shows no indication of TCE.

\section{Conclusions}

The three-dimensional simulation study indicates that a new we 11 , located north of TAN-1 and TAN-2, would remain outside the TCE plume for the simulated time of 20 years (through 2013). The new ive 11 is assumed to be completed below the Q-R interbed. While simulated TCE moves through the interbed and into the lower basalt, the plume at this depth is over one-half mile south of the new well location. Every effort was made to take the conservative approach in this study.

Adsorption, which would retard the movement of TCE through in interbed, was neglected. Also, because horizontal hydraulic conductivity was set equal to vertical, more crossflow is simulated than probably occurs. Despite the enhanced ability of TCE to move through the interbed and into the lower basalt, no TCE is seen at the proposed we 11 location at the depth of interest.

\section{References}

Feenstra, Stan, Douglas M. Mackay, and John A. Cherry, "A Method for Assessing Residual NAPL Bases on Organic Chemical Concentrations in Soil Samples," Spring 1991, Groundwater Monitoring Review, pp. 128-136.

Shook, G.M. and D.D. Faulder, "Validation of a Geothermal Simulator", EG\&G Report EP-9851, October 1991.

Vinsome, P.K.W., "TETRAD Users Manua1," 1990, Dyad Engineering, Calgary, Alberta, Canada.

Vinsome, P.K.W., and G.M. Shook, "Multi-Purpose Simulation," J. Petroleum Science and Engineering, March, 1993. 
Figure A1. Schematic of simulated area showing grid and proposed well completion.
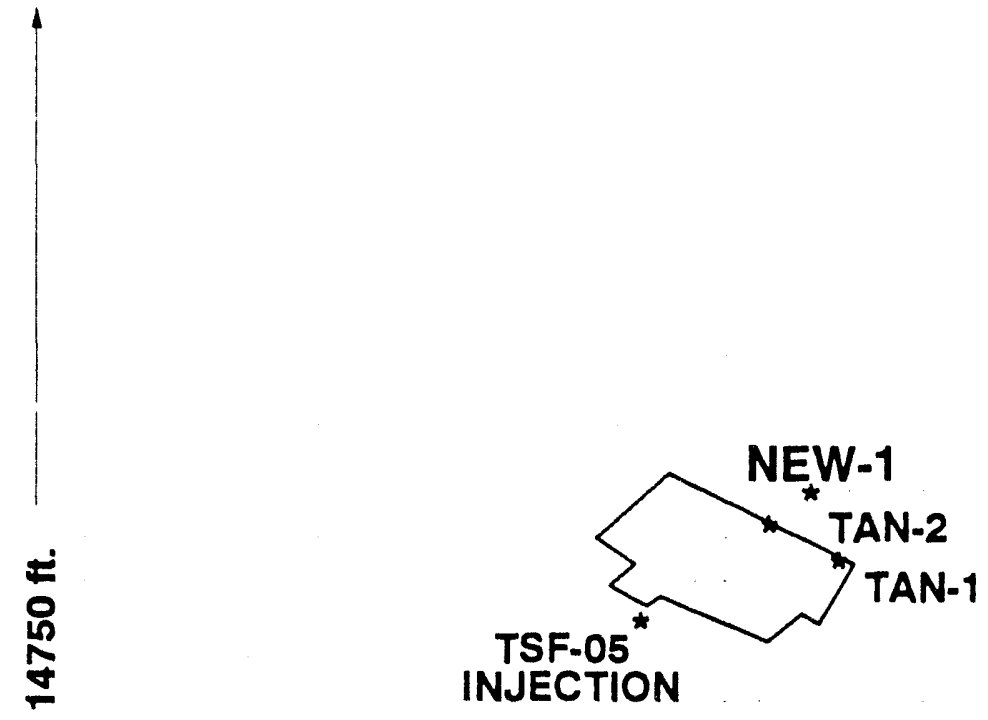

$15200 \mathrm{ft}$.

Proposed New Well

Completion Interval
Former Water Well

Completion Intervals

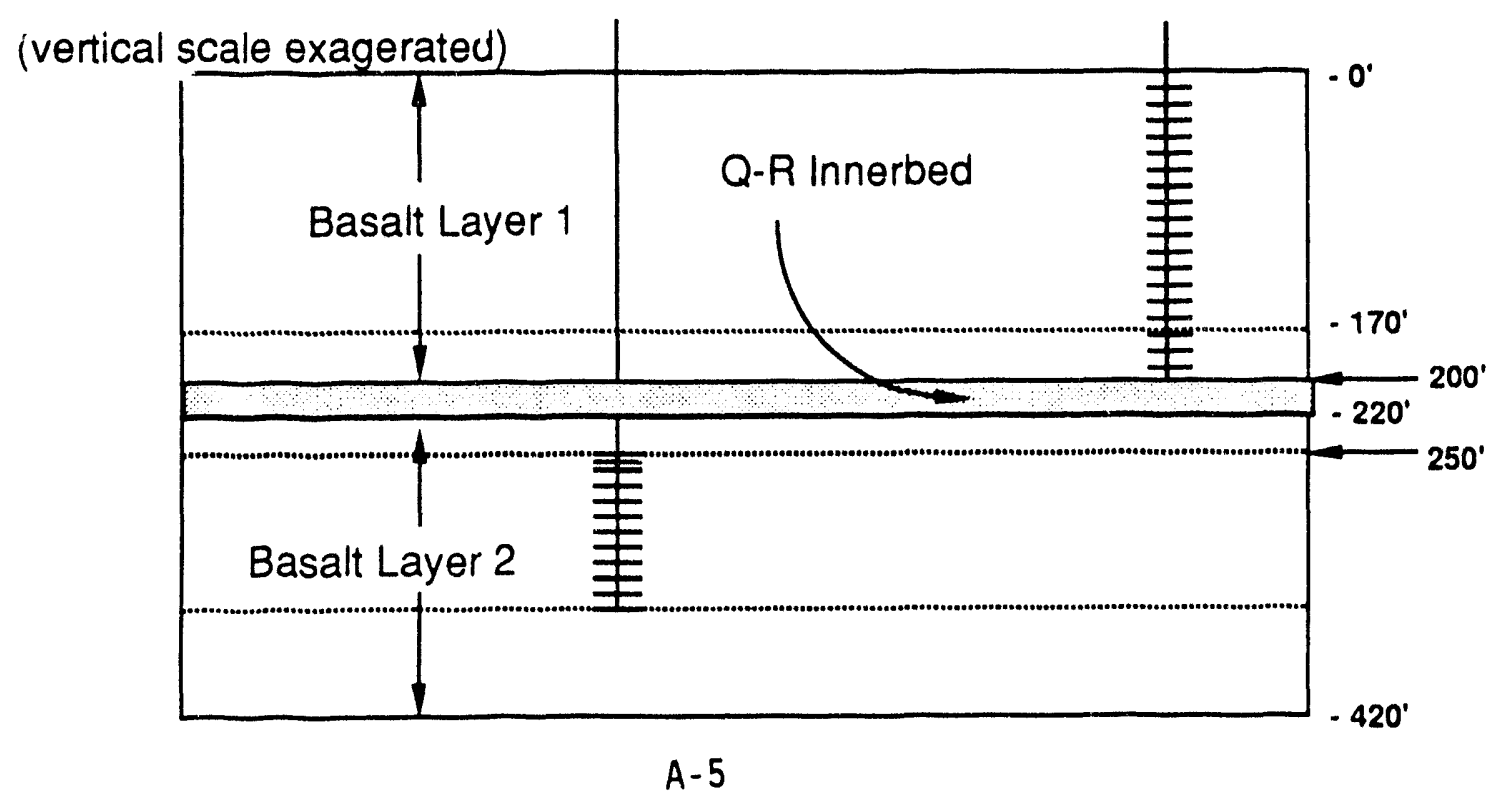


Figure A2. TCE Concentrations in Upper Basalt at $t=1993$, just prior to shutting off TAN-1 and TAN-2.

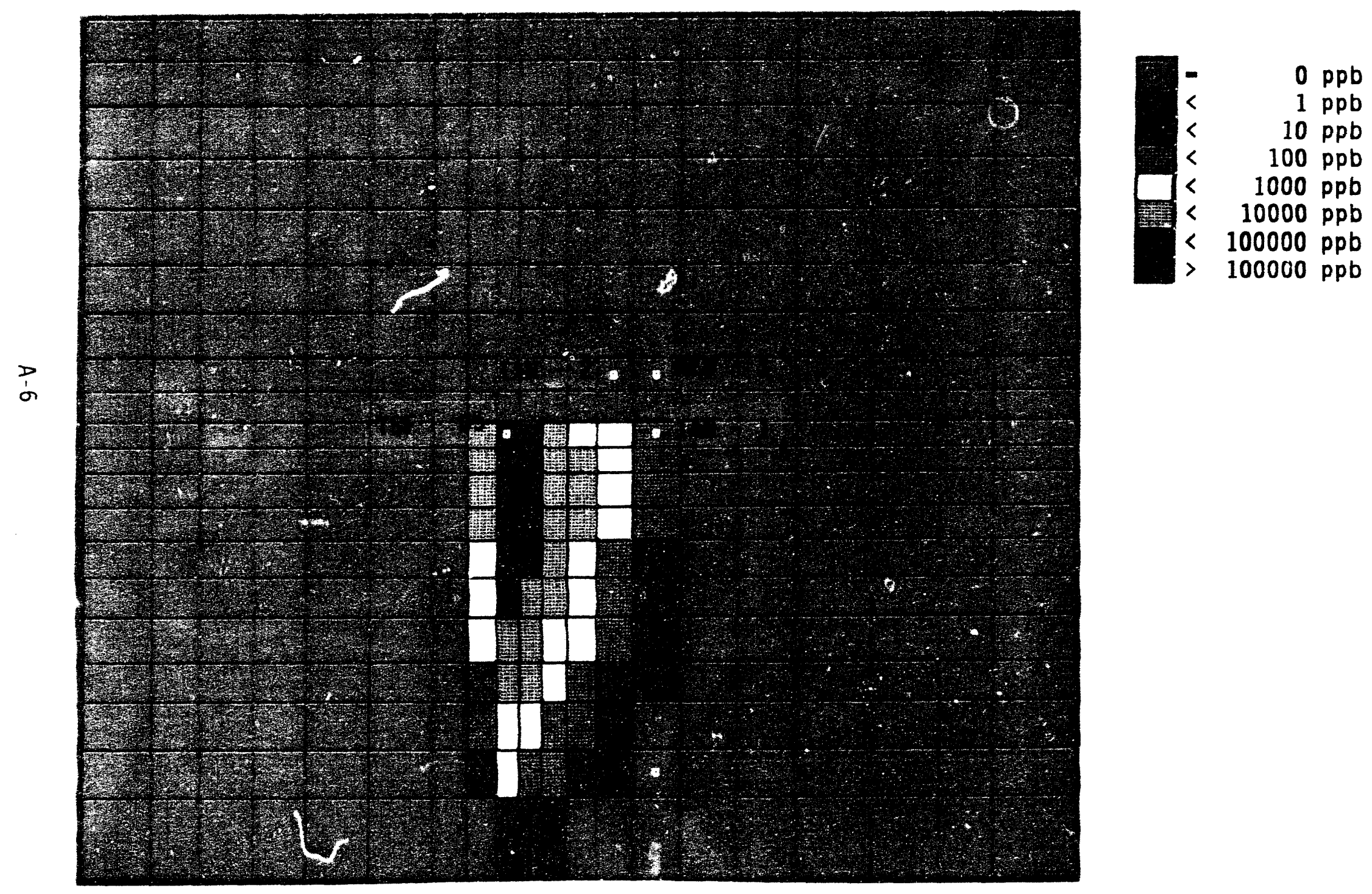


Figure A3. TCE Concentrations be low $Q-R$ Interbed at $t=1993$, just prior to shutting off TAN-1 and TAN-2.

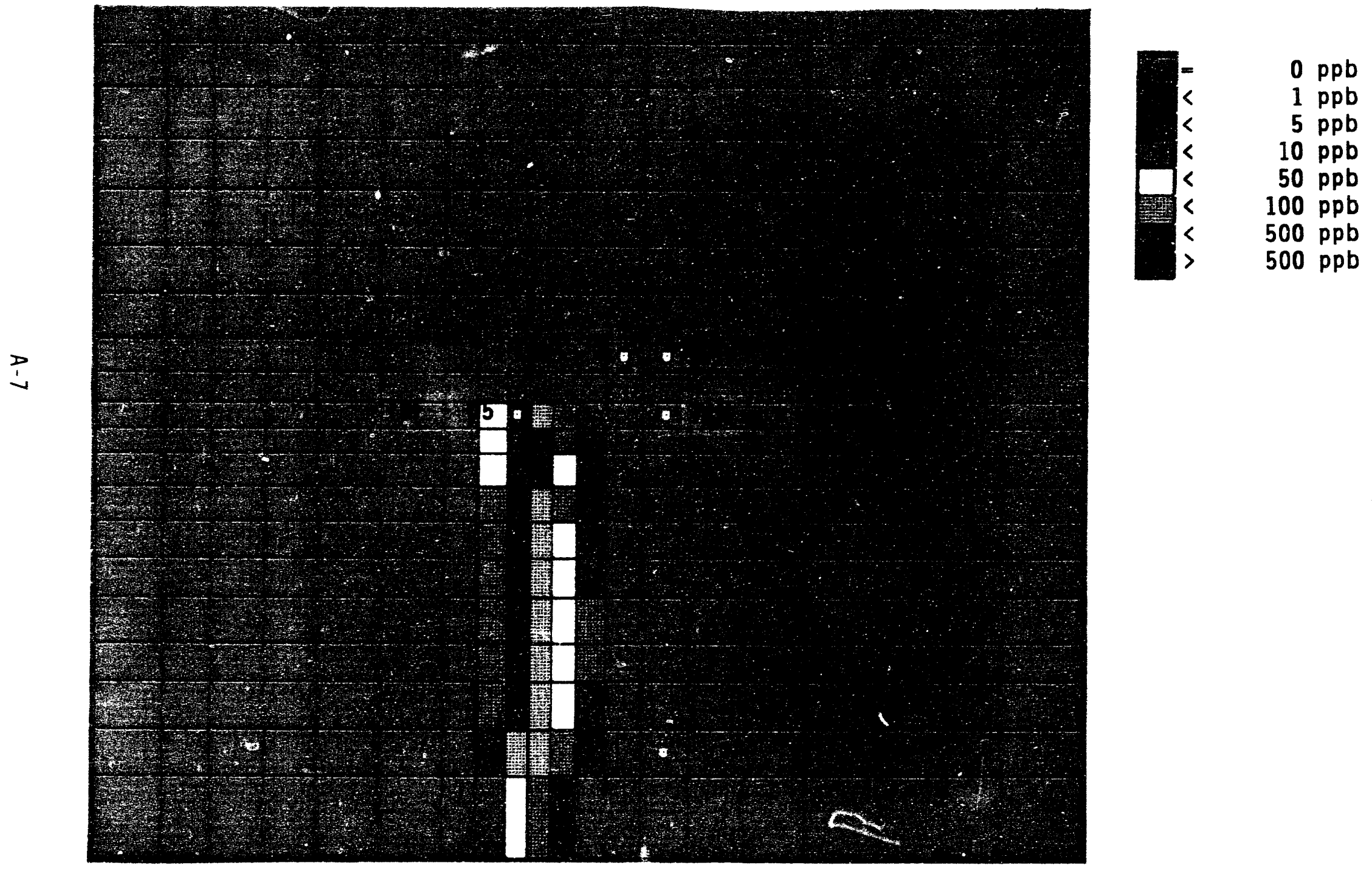


Figure A4. TCE Concentrations in Upper Basalt at $t=2013$. New We 11 has been pumped 20 years.
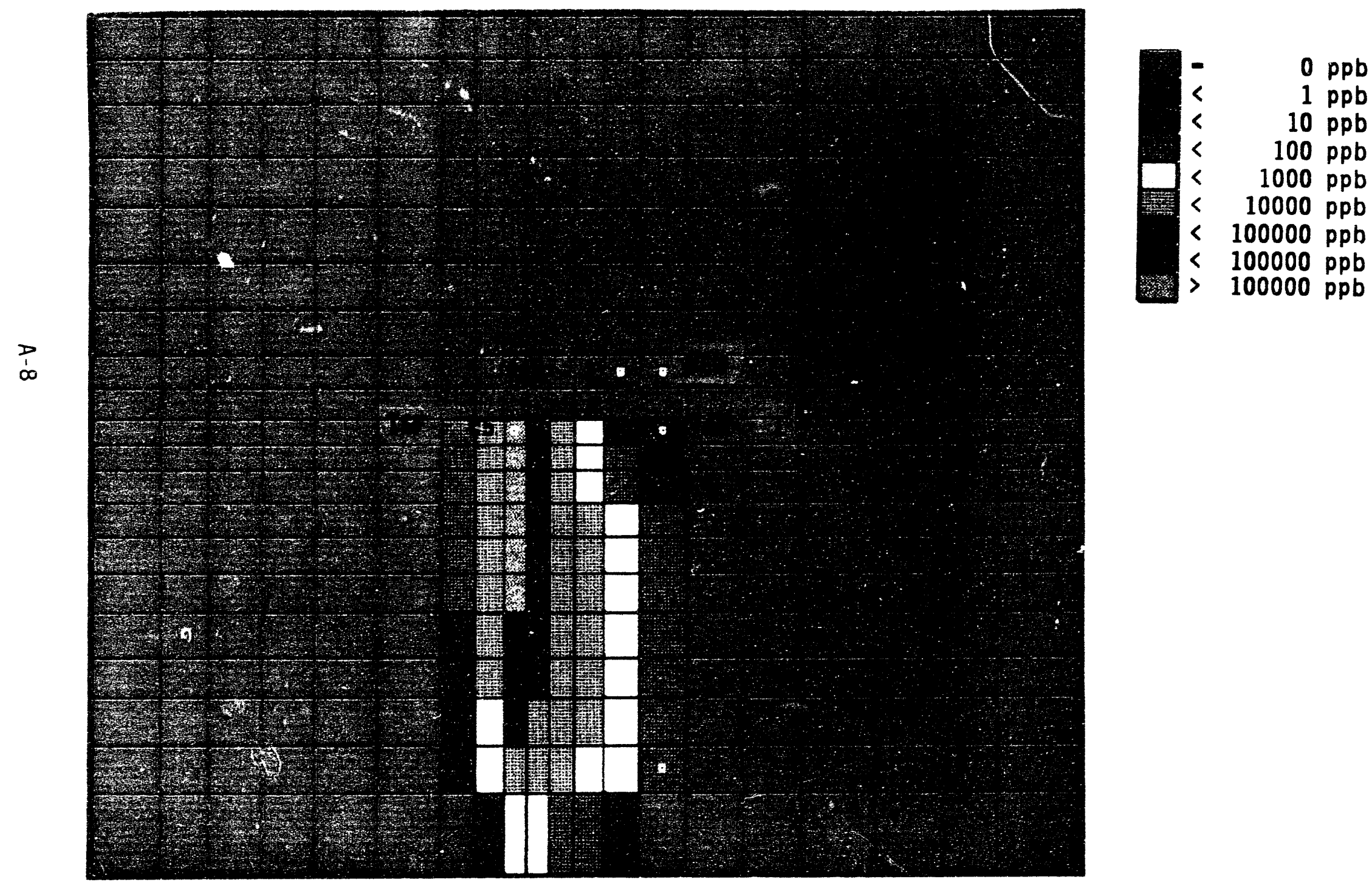
Figure A5. TCE Concentrations below $Q-R$ Interbed at $t=2013$. New We 11 has been pumped 20 years.

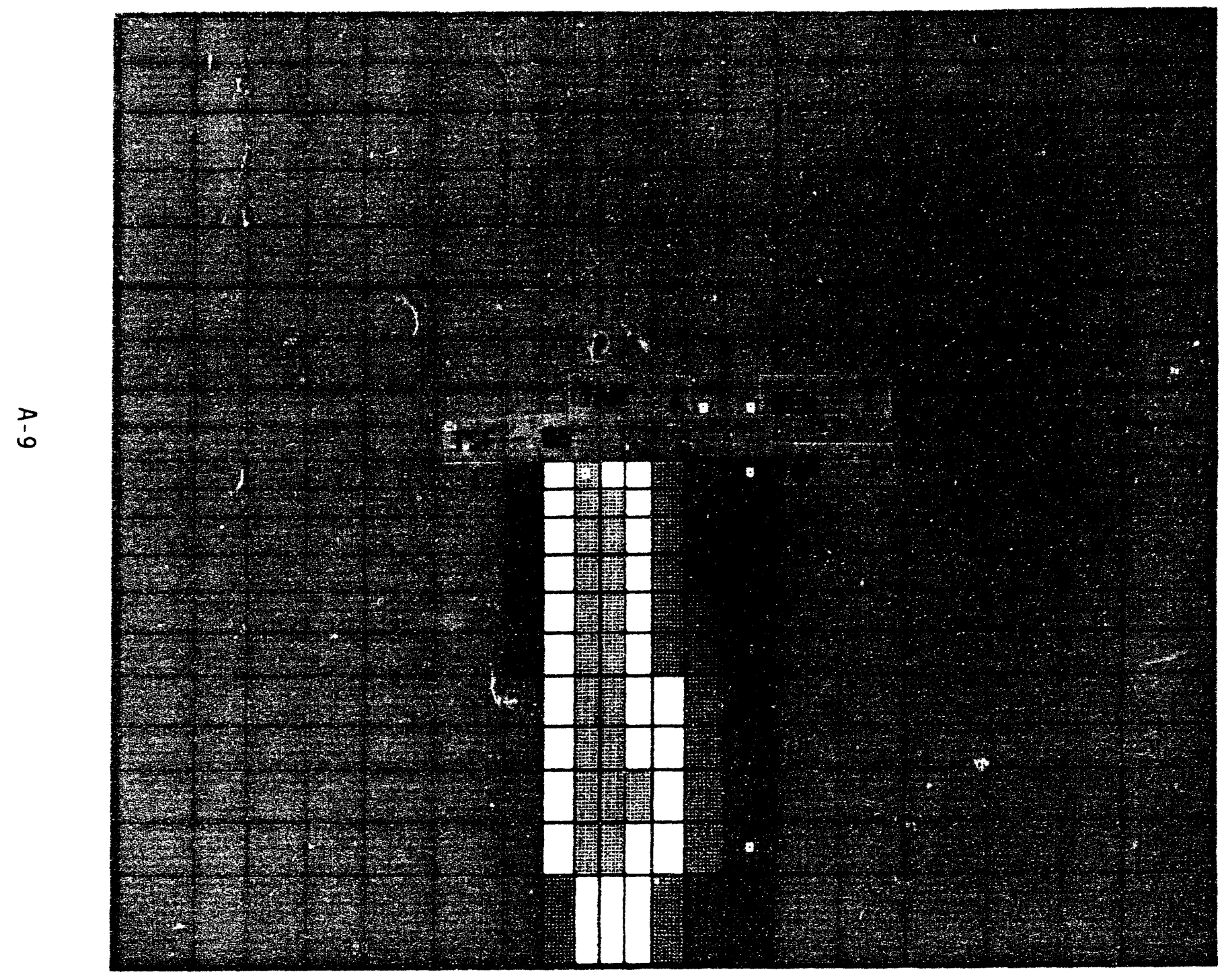


APPENDIX B

ESTIMATED COST OF DRILLING A 20 INCH WELL

B-1 
Water We11 Drilling Estimate

Twenty Inch Well Completion

Quantity Unit Unit

Price \$

1. Mobilization

Demobilization

10,000

6,000

2. Drill 38 inch hole and set 30 inch surface casing

40

If $\quad 325$

13,000

3. Drill 27 inch minimum

diameter hole

550

If $\quad 150$

82,500

4. Furnish and install 20 in.

$0 . D$. blank casing

350

If $\quad 48$

16,800

5. Furnish and install 20 in. pipe size well screen

200

if $\quad 78$

15,600

6. Furnish and install gravel pack

240

If $\quad 37.50$

9,000

7. Install sanitary grout seal

310

If $\quad 35$

10,850

8. Well development by air

lift and water jetting

48

hr $\quad 375$

18,000

Total

181,750 
APPENDIX C

COPIES OF COLOR OVERHEAD TRANSPARENCIES

$c-1$ 


\section{TAN Ground Water Plume FY-92}

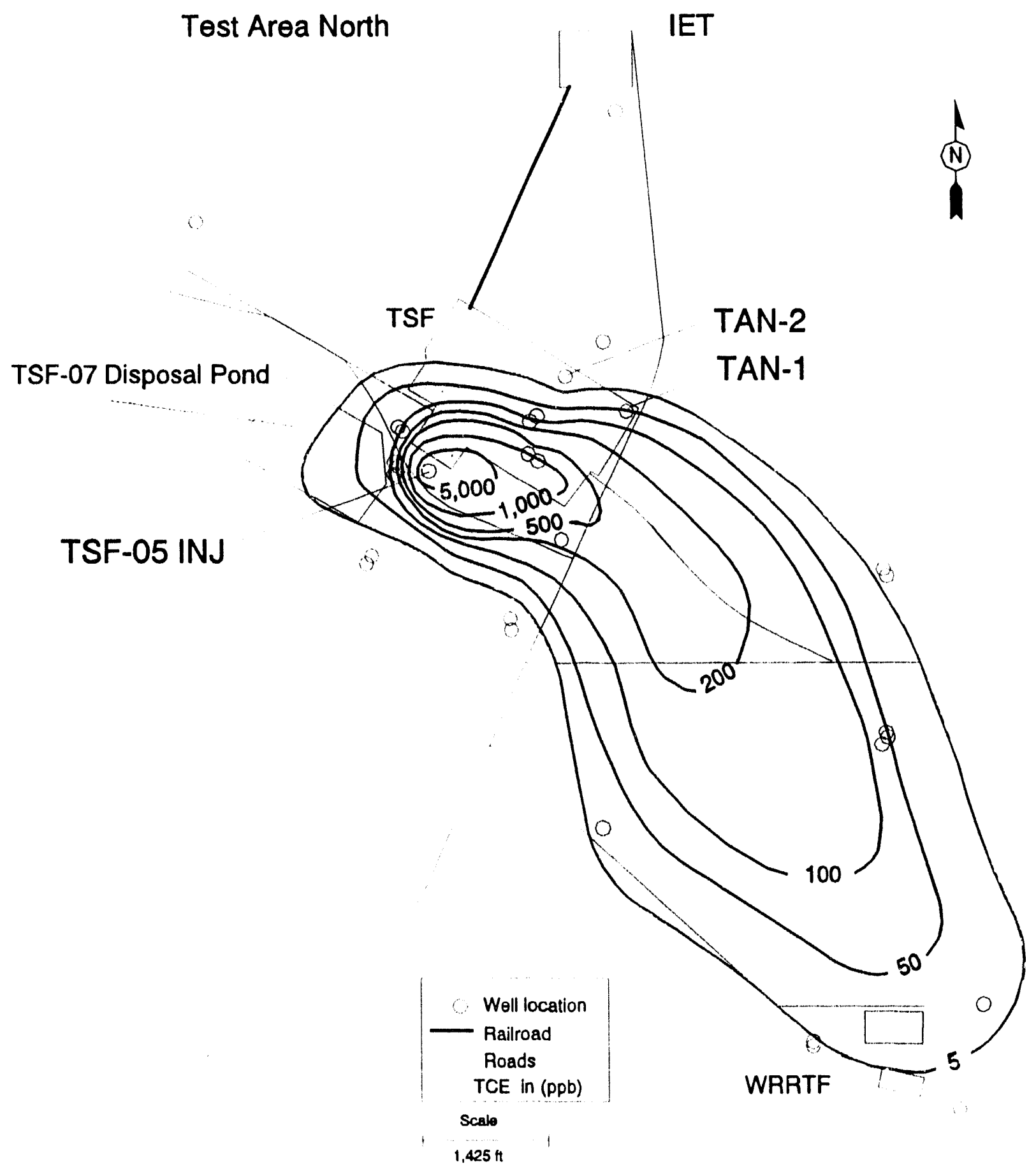

TANTCE1.WPG 
Explanation

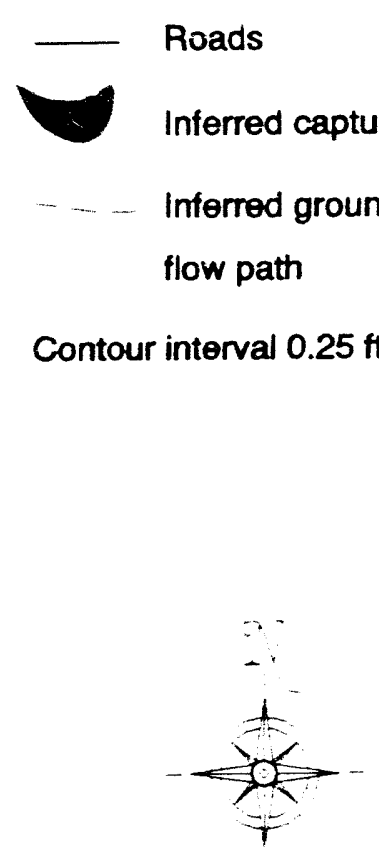

Scale (ft)

0
1500

\section{足}

TAN500PW

03/04/93

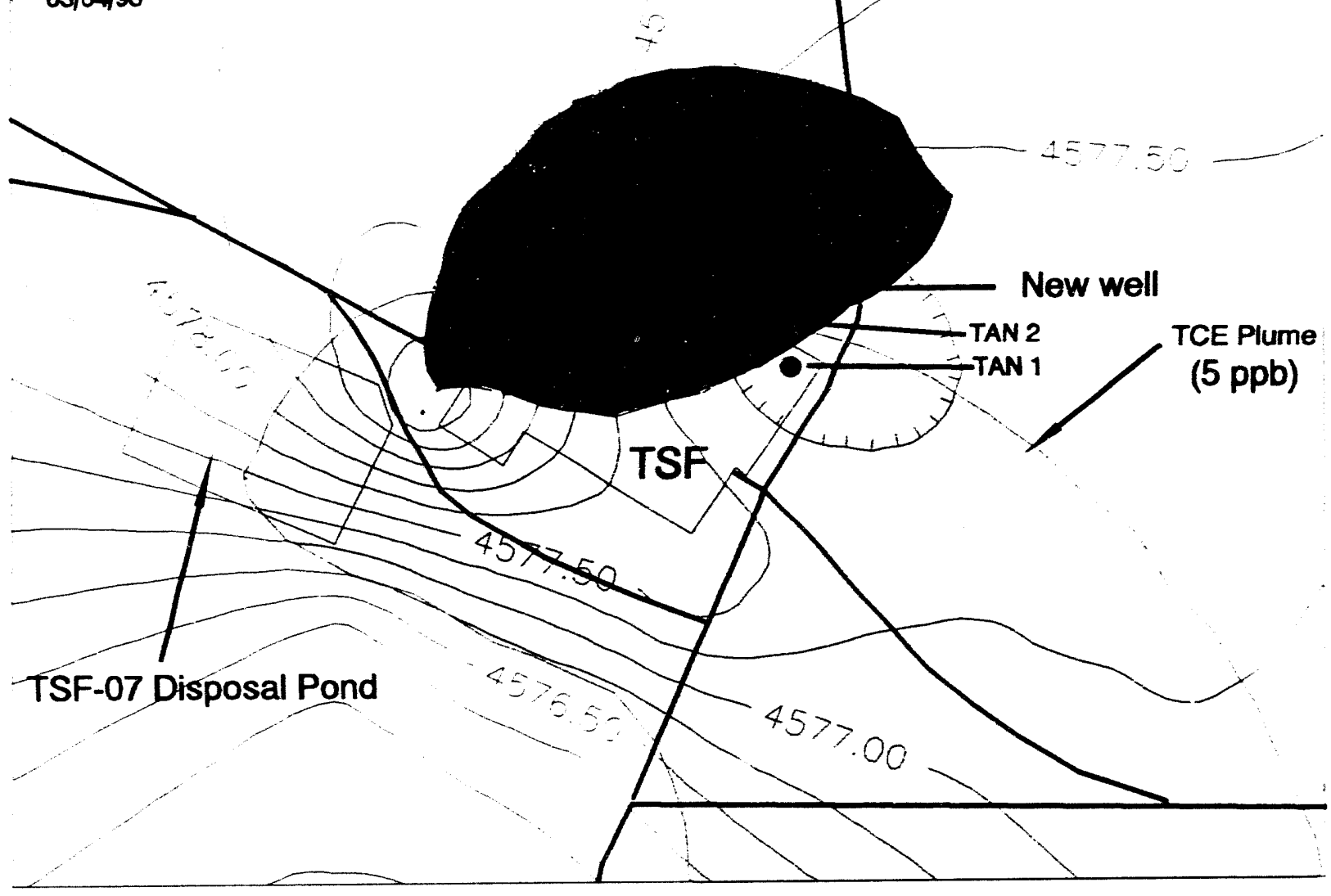

Scenario 1.

3000

4500

Five Year Capture Zone For Now TAN Well Located $500 \mathrm{ft}$ North Of TAN-1 (Pumping Rate 45 million gallons/year) 
Scenario 2. Five year capture zone for new TAN well located out of the influence of contaminant sources (pumping rate $\mathbf{4 5}$ million gallons/year).

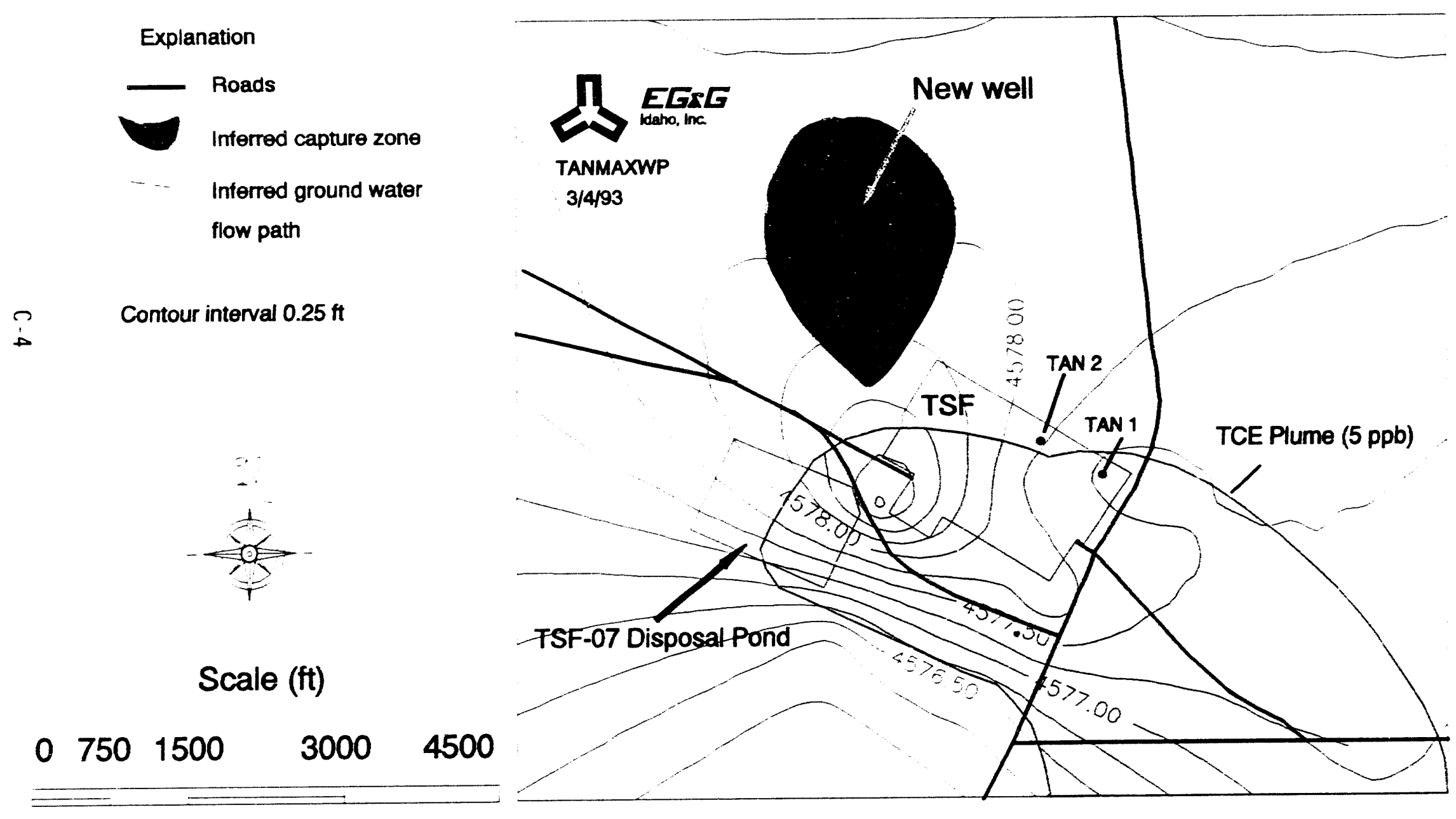




\section{Scenario 2. Ten Year Capture Zone For Well Located Northwest Of Contaminant Source (Pumping Rate 45 million gallons/year)}

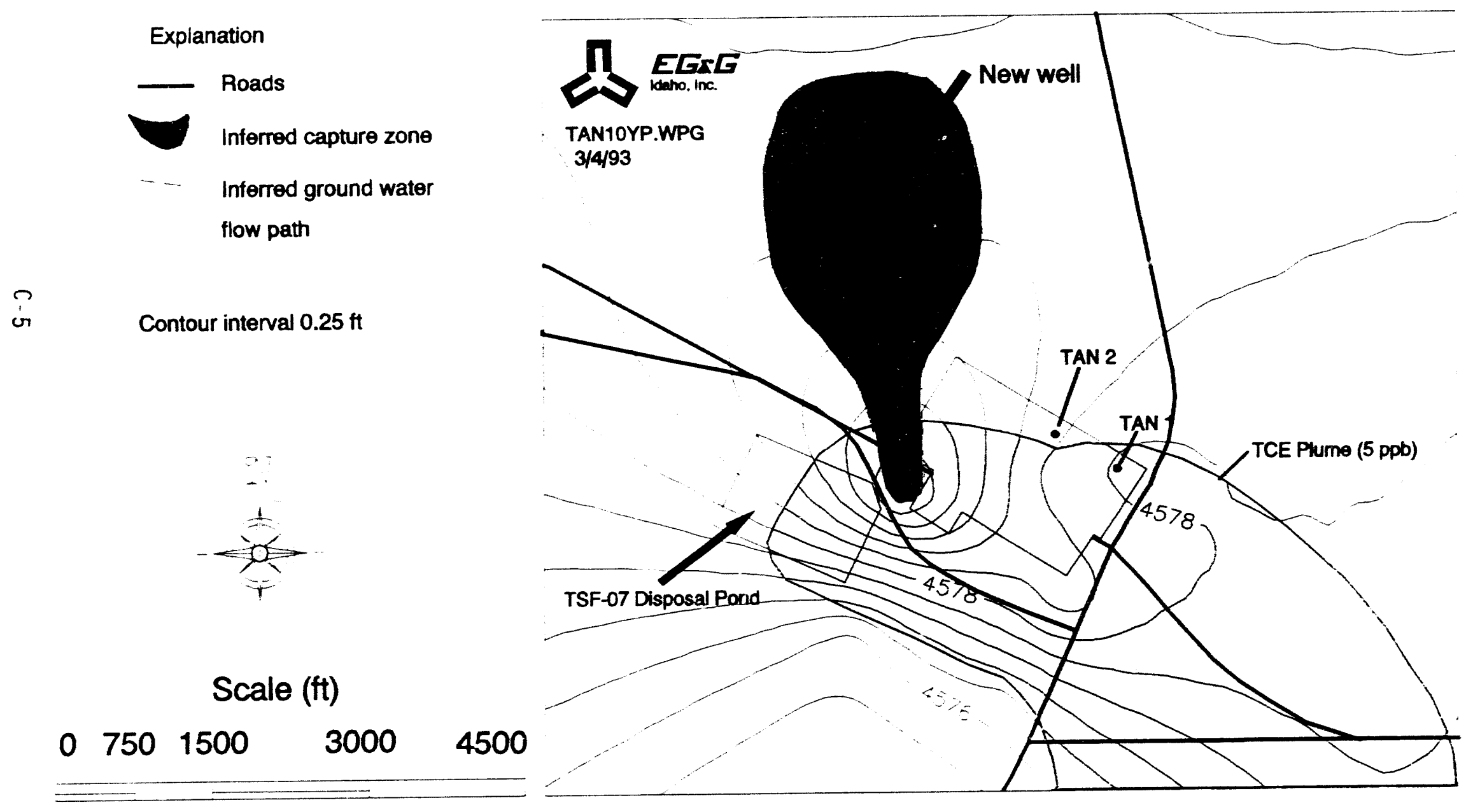




\section{Scenario 3. Cross Section With TAN 1 Extended Below Q-R Interbed}

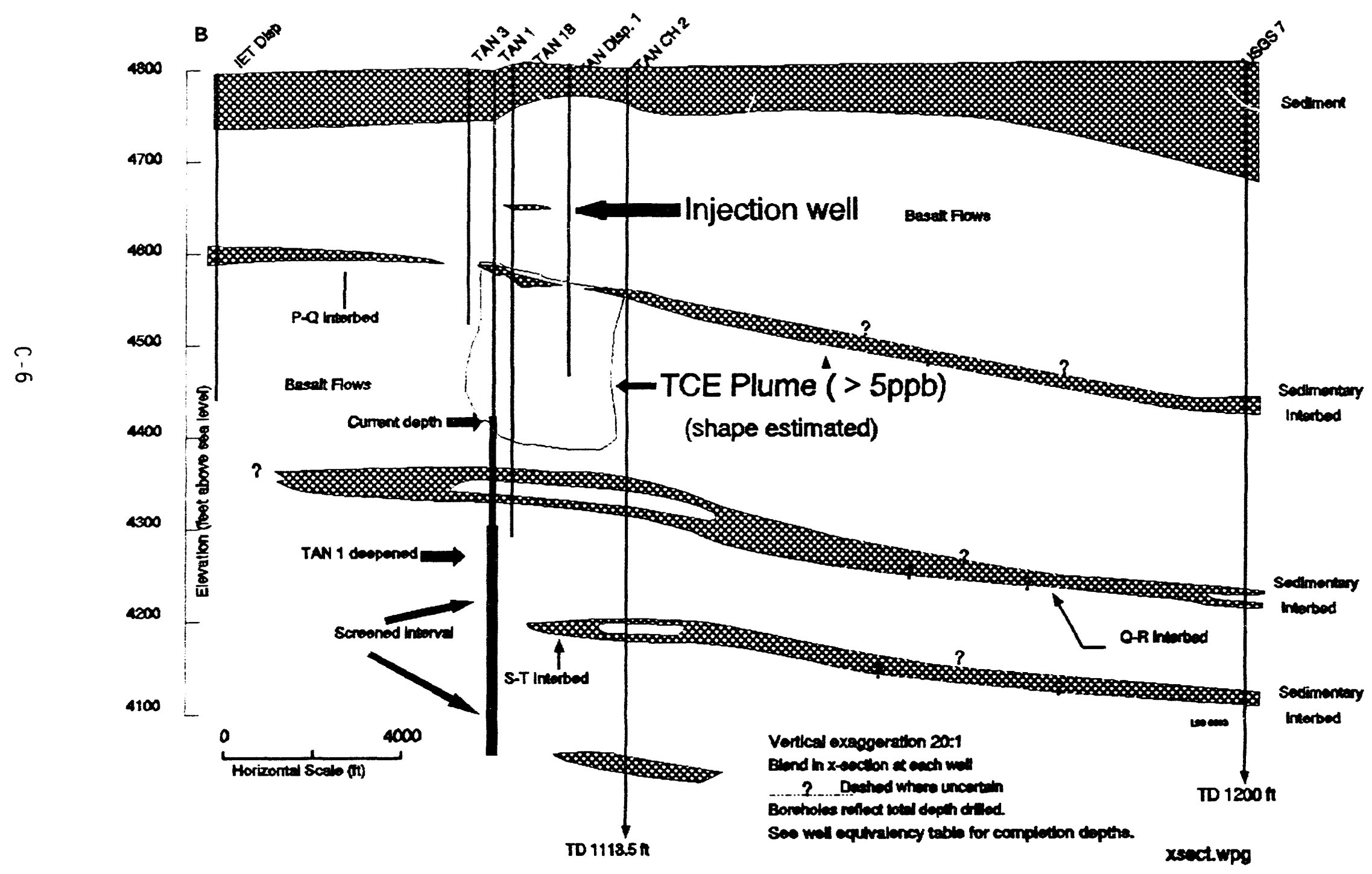




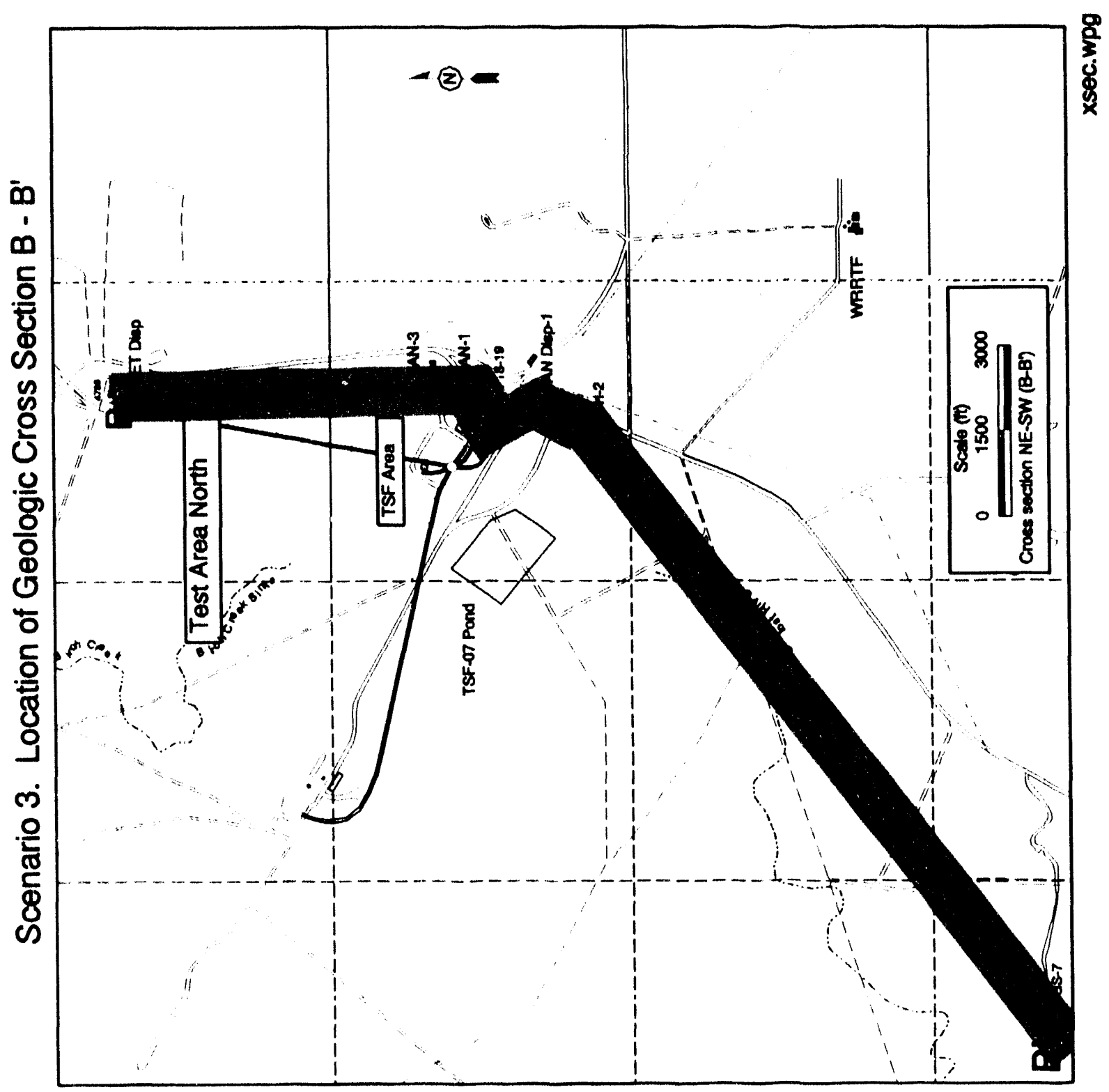

C. 7 


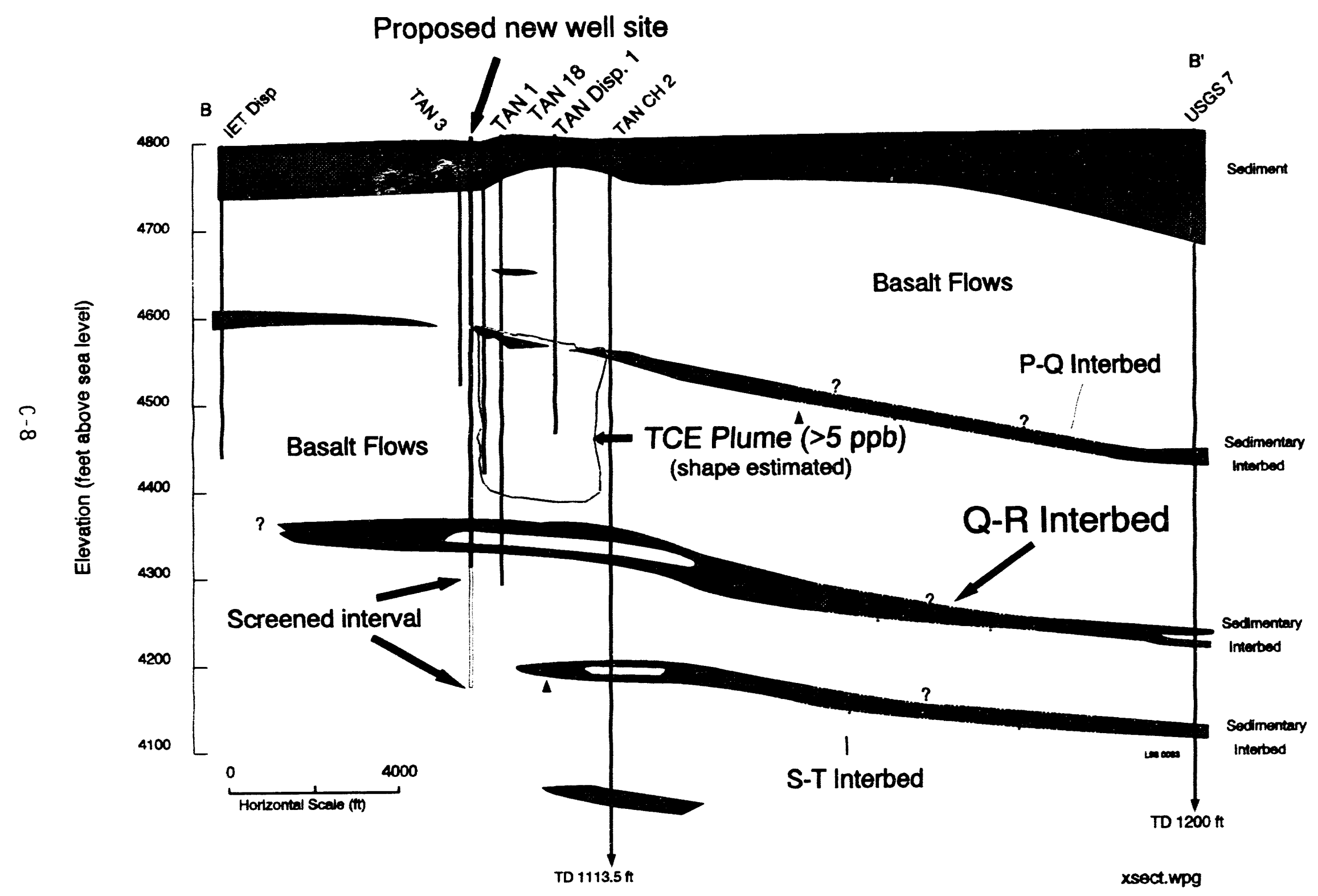




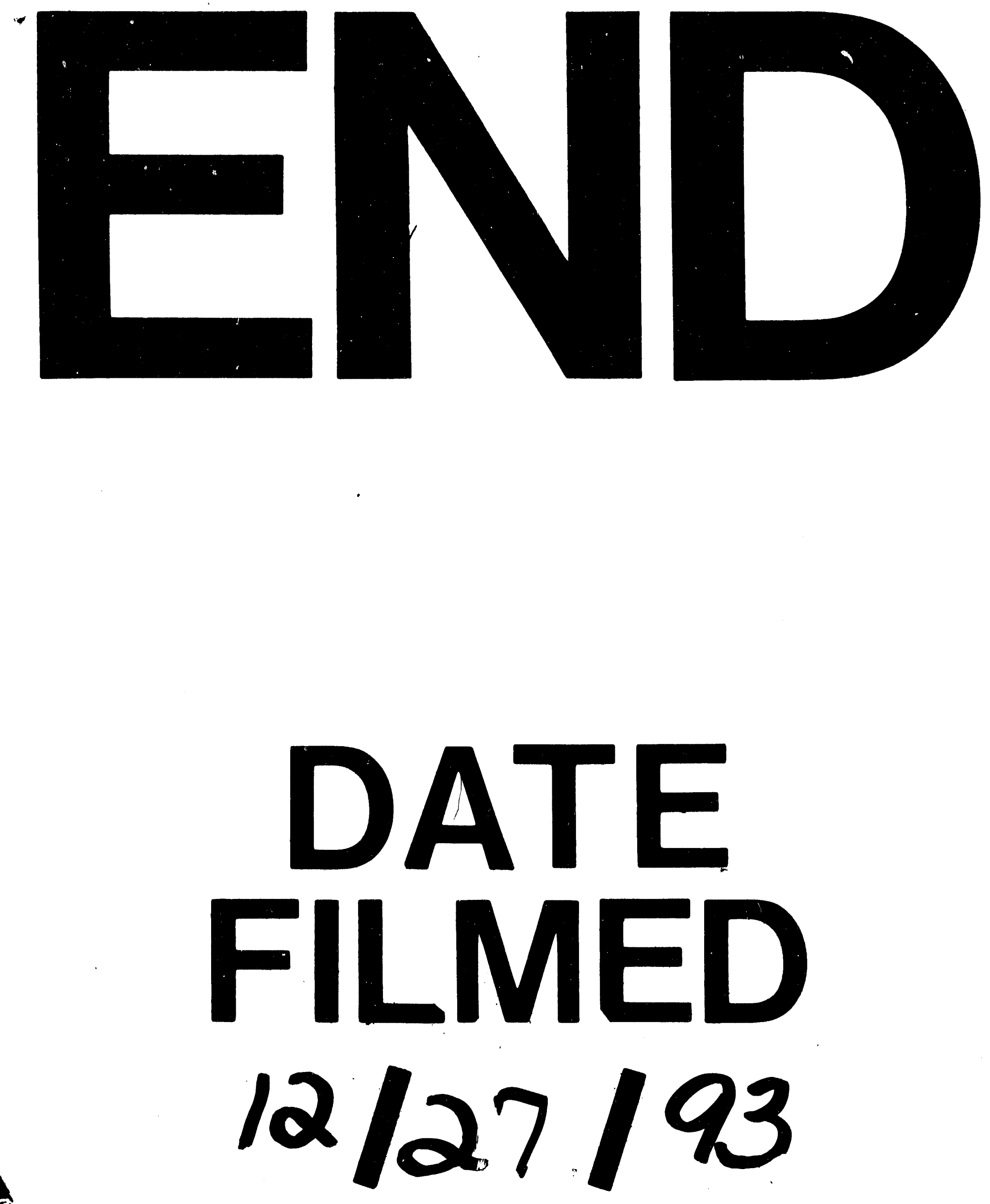

1 
